\title{
Relationships between nitrogen and phosphorus forms and ratios and the development of dinoflagellate blooms in the East China Sea
}

\author{
Ji Li1 ${ }^{1, *}$, Patricia M. Glibert ${ }^{1}$, Mingjiang $\mathrm{Zhou}^{2}$, Songhui $\mathrm{Lu}^{3}$, Douding $\mathrm{Lu}^{4}$ \\ ${ }^{1}$ University of Maryland Center for Environmental Science, Horn Point Laboratory, PO Box 775, Cambridge, \\ Maryland 21613, USA \\ ${ }^{2}$ Institute of Oceanology, Chinese Academy of Sciences, Qingdao 266071, China \\ ${ }^{3}$ Institute of Hydrobiology, Jinan University, Guangzhou 510632, China \\ ${ }^{4}$ Second Institute of Oceanography, State Oceanographic Administration, Hangzhou 310012, China
}

\begin{abstract}
During late spring and early summer of 2005, large-scale (>15000 km²), mixed dinoflagellate blooms developed along the the coast of the East China Sea. Karenia mikimotoi was the dominant harmful algal bloom species in the first stage of the bloom (late May) and was succeeded by Prorocentrum donghaiense approximately $2 \mathrm{wk}$ later. Samples were collected from different stations along both north-south and west-east transects, from the Changjiang River estuary to the south Zhejiang coast, during 3 cruises of the Chinese Ecology and Oceanography of Harmful Algal Blooms Program, before and during the bloom progression. Nitrogen isotope tracer techniques were used to measure rates of $\mathrm{NO}_{3}{ }^{-}, \mathrm{NH}_{4}{ }^{+}$, urea, and glycine uptake during the blooms. High inorganic nitrogen (N), but low phosphorus (P) loading from the Changjiang River led to high dissolved inorganic N:dissolved inorganic $\mathrm{P}$ ratios in the sampling area and indicate the development of $\mathrm{P}$ limitation. The rates of ${ }^{15} \mathrm{~N}$-uptake experiments enriched with $\mathrm{PO}_{4}{ }^{3-}$ were enhanced compared to unamended samples, suggesting $\mathrm{P}$ limitation of the $\mathrm{N}$-uptake rates. The bloom progression was related to the change in availability of both organic and inorganic $\mathrm{N}$ and $\mathrm{P}$. Reduced $\mathrm{N}$ forms, especially $\mathrm{NH}_{4}{ }^{+}$, were preferentially taken up during the blooms, but different bloom species had different rates of uptake of organic N substrates. K. mikimotoi had higher rates of urea uptake, while $P$. donghaiense had higher rates of glycine uptake. Changes in the availability of reduced $\mathrm{N}$ and the ratios of N:P in inorganic and organic forms were suggested to be important in the bloom succession. Nutrient ratios and specific uptake rates of urea were similar when compared to analogous blooms on the West Florida Shelf.
\end{abstract}

KEY WORDS: Harmful dinoflagellate blooms $\cdot \mathrm{N}$ uptake $\cdot$ East China Sea $\cdot \mathrm{N}: \mathrm{P}$ ratio $\cdot$ Prorocentrum $\cdot$ Karenia

Resale or republication not permitted without written consent of the publisher

\section{INTRODUCTION}

Large-scale dinoflagellate blooms in the Changjiang (Yangtze) River estuary (CJRE) and the adjacent area of the East China Sea (ECS) in late spring and early summer have been recorded in the past decade (Zhou et al. 2003). The dinoflagellate Prorocentrum donghaiense has been found to be the dominant species in this region since large-scale field studies began in 2000. Blooms have been observed from late April to
May almost every year (Tang et al. 2006), but the scale of the blooms has increased from 1000s of square kilometers to $>15000 \mathrm{~km}^{2}$ recorded from 2000 to 2005 .

These more frequent and persistent algal blooms are thought to result from increasing nutrient input to the ECS (Anderson et al. 2002, Zhou et al. 2003, Glibert \& Burkholder 2006). The major sources of nitrogen (N) and phosphorus (P) are terrestrial inputs from the watersheds of the Changjiang River and other major rivers (e.g. Qiantangjiang River, Yongjiang River). The 
Changjiang River is the third longest river in the world. Its annual freshwater input is $9.32 \times 10^{11} \mathrm{~m}^{3}$, and the annual input, estimated in 1998, of N was $2.9 \times 10^{6} \mathrm{t}$ and of P $0.13 \times 10^{6} \mathrm{t}$ (Shen et al. 2003, Shen 2006), representing a doubling of nutrient inputs in the previous 20 yr (Shen et al. 2003). While both $\mathrm{N}$ and $\mathrm{P}$ inputs by human usage have increased, the recent increases have been far greater in N. In 2005, China's nitrogenous fertilizer production reached $36 \times 10^{6} \mathrm{t}$, including $20 \times 10^{6} \mathrm{t}$ of urea fertilizer, a 5 -fold increase since 1989 (IFIA 2007). The annual dissolved inorganic nitrogen (DIN) load from the Changjiang River coastal waters has reached $1.4 \times 10^{6} \mathrm{t}$, which is higher than DIN loads from the Mississippi and Amazon rivers (Goolsby \& Battaglin 2000, Duan et al. 2008). The N loading of the Changjiang River results from the large human population at its watershed and concomitant agriculture and industrial activity. The 440 million people living in the Changjiang River watershed occupy 4 of the 10 most populated cities in China. This area produces $>32 \%$ of the national agriculture output and $>35 \%$ of the industrial output (Xing \& Zhu 2002). Furthermore the Changjiang delta area is the most developed area in China.

The freshwater of the Changjiang River extends offshore and forms a large plume, called the Changjiang River Diluted Water (CRDW), which is characteristically high in $\mathrm{N}$, but relatively low in $\mathrm{P}$. As a result, the coastal area of the ECS has a relatively low $\mathrm{P}$ concentration. The total $\mathrm{N}$ of the CRDW has been shown to be about 70 to $110 \mu \mathrm{mol} \mathrm{N} \mathrm{l}{ }^{-1}$, and is mostly in the form of $\mathrm{NO}_{3}{ }^{-} \mathrm{N}$ (Shen

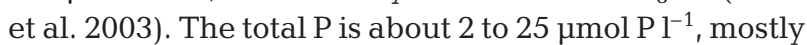
as particulate $\mathrm{P}_{;} \mathrm{PO}_{4}{ }^{3-}-\mathrm{P}$ is only about 10 to $20 \%$ of the total P (Yan \& Zhang 2003). As a result, the DIN to dissolved inorganic phosphorus (DIP) ratio is typically $>100$ inside the river's mouth (Chai et al. 2006, Zhang et al. 2007). Limitation by $P$ has also been reported along the coast of China, from the Yellow River continental shelf in the north (Turner et al. 1990) to the Pearl River estuary (Yin et al. 2004), and coastal South China Sea (Harrison et al. 1990) in the south.

Compared to the P-limited Changjiang River waters, there is a branch of the Kuroshio current, the Taiwan Warm Current (TWWC), which is P replete (Tang et al. 2000, Fang 2004). This bottom current passes the Taiwan Strait and flows northward along the coast, bringing similar levels of $\mathrm{N}$ as found in the ECS, but 8 to 17 times more DIP than in the Changjiang, with seasonal variation (Shen et al. 2003, Li et al. 2007). The TWWC is thought to be an important P source for the coastal ECS. The strength of the TWWC is weak in the winter, but increases in the early spring. The current rises when it reaches the shallow continental shelf, and when it reaches the CJRE area, it forms an upwelling zone (Chen et al. 1995). Mixing between the CRDW and the TWWC may result in P being carried to the surface waters and thus becoming available to the phytoplankton community.

Although the general hydrography and nutrient loading rates in the ECS have been studied, the rates of nutrient uptake and the nutritional preferences of the phytoplankton during blooms are still unknown. A comprehensive survey of the bloom area was conducted in 2005. Our objectives in the present study were to investigate the nutrient concentrations in the bloom area, to assess the uptake rates of $\mathrm{NO}_{3}{ }^{-}, \mathrm{NH}_{4}{ }^{+}$ and dissolved organic nitrogen (DON), and to describe the relationships between the ambient $\mathrm{N}: \mathrm{P}$ ratios and phytoplankton community composition. The bloom of 2005 was unusual in composition, with a progression of dinoflagellate species, beginning with Karenia mikimotoi, followed by Prorocentrom donghaiense, and, lastly, Noctiluca scintillans. The pre-bloom period was dominated by diatoms. This unusual progression provided the opportunity to explore the relationships between specific harmful algal bloom (HAB) species and nutrient dynamics. N:P ratios and N-uptake rates are also compared based on similar measurements made in different assemblages dominated by $K$. brevis, mixed dinoflagellates and diatoms on the southwest Florida Shelf.

\section{MATERIALS AND METHODS}

Sampling sites. Sampling was conducted during 3 cruises in 2005 in the coastal area of the ECS, between 27.2 and $31.5^{\circ} \mathrm{N}$ (Fig. 1). The first cruise was from April 23 to May 18, the second cruise was from May 25 to June 19, and the third cruise was from June 22 to July 1,2005. Transects were set between the 20 and $60 \mathrm{~m}$ isobaths.

Sampling and parameter measurements. Water was collected using 301 Niskin bottles from near the surface and from the sub-surface chlorophyll maximum depth, which was usually around $10 \mathrm{~m}$ (detected by a YSI multiparameter sensor; Yellow Springs Instrument Co.), or using a bucket for the surface sample at some stations. All samples were collected around noon. Water samples were subsequently divided for different analyses and experimental purposes, as described below. Cell samples were identified microscopically during the cruises. Water samples were filtered though pre-combusted $\left(2 \mathrm{~h}\right.$ at $\left.400^{\circ} \mathrm{C}\right)$ Whatman $\mathrm{GF} / \mathrm{F}$ filters and stored at $-20^{\circ} \mathrm{C}$ for subsequent nutrient analysis. Filters were stored frozen for later pigment analysis, and particulate organic carbon and nitrogen (POC and PON) analysis.

All samples were transported frozen to Horn Point Laboratory and analyzed within 6 mo. Concentrations 


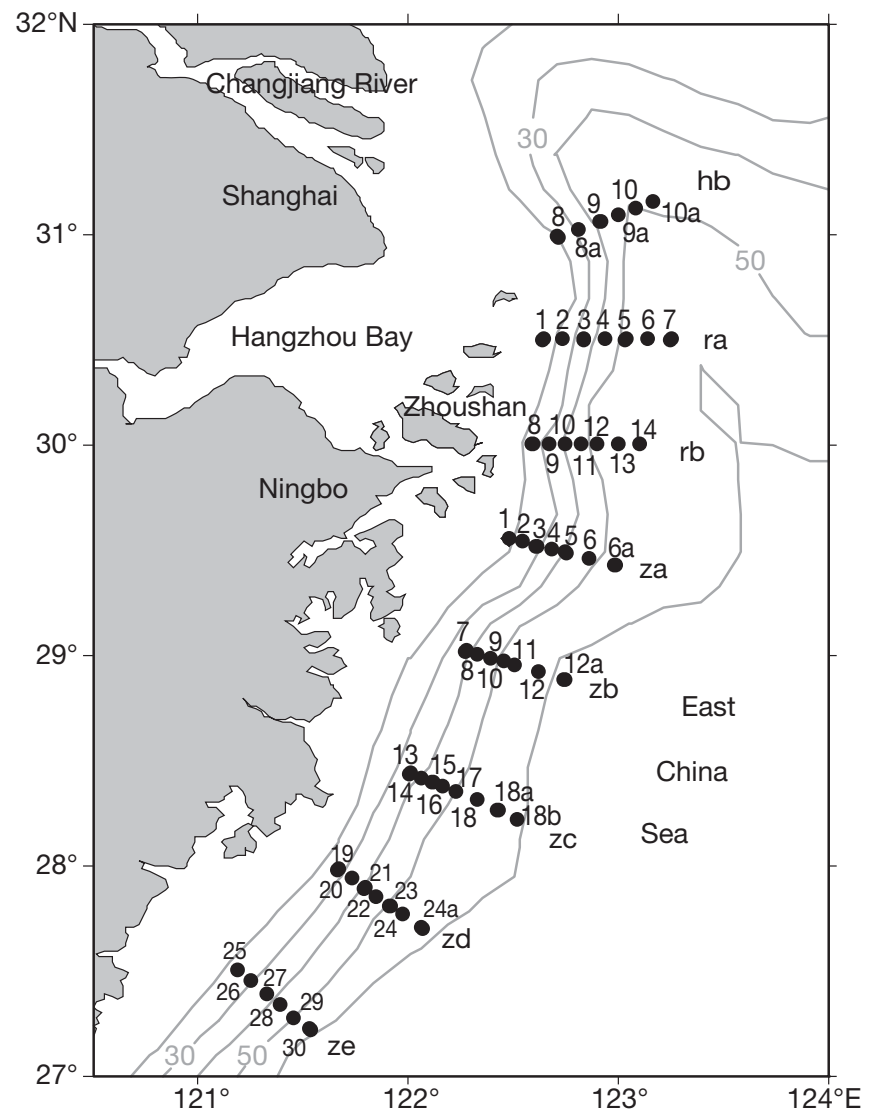

Fig. 1. Locations of the sampling stations along transects during cruises to study dinoflagellate blooms in the East China Sea, 2005

of ambient inorganic nutrients $\left(\mathrm{NO}_{3}{ }^{-}+\mathrm{NO}_{2}{ }^{-}-\mathrm{N}, \mathrm{NH}_{4}{ }^{+}-\right.$ $\mathrm{N}, \mathrm{PO}_{4}{ }^{3-}-\mathrm{P}, \mathrm{Si}[\mathrm{OH}]_{4}-\mathrm{Si}$ ) were determined using a Technicon Auto-Analyzer (Lane et al. 2000). Total dissolved nitrogen (TN) and phosphorus (TP) were measured using the persulfate method (Valderrama 1981), and dissolved organic nitrogen and phosphorus (DON and DOP) were calculated by subtracting the inorganic concentration from TN and TP. Concentrations of dissolved free amino acid (DFAA) were determined by fluorometric analysis according to Lindroth \& Mopper (1979), and urea was analyzed using the method of Revilla et al. (2005). DFAA concentrations were used to approximate the glycine concentrations in the $\mathrm{N}$ uptake rate calculations, recognizing that an overestimate of substrate concentration will lead to overestimated uptake rates. Glycine is generally considered to be a dominant amino acid (Degens \& Mopper 1976), but the rates should be considered potential rates based on the uncertainty of their contribution to the DFAA pool. Filters for POC and PON were dried at $50^{\circ} \mathrm{C}$ for $24 \mathrm{~h}$. POC and PON concentrations were measured with a CHN elemental analyzer using acetanilide as the standard.
Pigment analyses were performed by high-performance liquid chromatography (HPLC) according to the method of Van Heukelem \& Thomas (2001). Over 20 types of pigments were analyzed including chlorophyll a (chl a) and accessory pigments. The relative abundances of specific pigments were used to evaluate the abundance of specific algae. Fucoxanthin was used to indicate the presence of diatoms (Boczar \& Palmisano 1990, Yao et al. 2006), although it is recognized that it may also be contained in some dinoflagellates. Peridinin was used as an indicator of photosynthetic dinoflagellates (e.g. Prorocentrum donghaiense). The pigment gyroxanthin-diester was used as a specific indicator of Karenia spp. (Chang \& Trench 1982, Le et al. 2001, Richardson \& Pinckney 2004). The absolute values of specific pigments were used to indicate the abundance of the species groups in the water, and the ratios of specific pigments to chl a were used to indicate the relative abundance of the species in the phytoplankton community. Modeling software, such as CHEMTAX (Mackey et al. 1996), was not used to relate pigment concentrations to species, due to the need for a specific pigment ratio from reference cultures, which were not available (Lewitus et al. 2005). Microscopic enumerations (not shown) verified the dominance of the particular algal groups and thus the appropriateness of the indicator pigments chosen.

Nitrogen-uptake experiments. Experiments were conducted in 2005 on May 7, 8, 9, 13, and 28 and June $3,9,11,16$, and 23. These periods covered the period from before dinoflagellate dominance to the late phase of the Prorocentrum donghaiense bloom progression. One experiment was conducted per day. Sample water was transferred into a clear 201 carboy immediately after collection, and experiments were started immediately. Water was dispensed into acidclean, $250 \mathrm{ml}$ bottles and inoculated with ${ }^{15} \mathrm{~N}$-labeled substrates $\left(\mathrm{NO}_{3}{ }^{-}, \mathrm{NH}_{4}{ }^{+}\right.$, urea, and glycine). ${ }^{15} \mathrm{~N}$-labeled $\mathrm{NO}_{3}{ }^{-}$was added at $1 \mu \mathrm{mol} \mathrm{N} \mathrm{l}{ }^{-1} ;{ }^{15} \mathrm{~N}$-labeled $\mathrm{NH}_{4}{ }^{+}$and urea were added at $0.5 \mu \mathrm{mol} \mathrm{N} \mathrm{I}^{-1}$; and ${ }^{15} \mathrm{~N}$-labeled

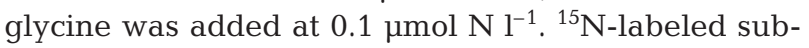
strates represented $\sim 10$ to $50 \%$ of final ambient concentrations. Incubations were $0.5 \mathrm{~h}$ on deck in a flowing seawater incubator around noon, with neutral density screening to simulate 25 to $50 \%$ of the natural irradiation. At the end of the incubation, samples were filtered onto pre-combusted $\left(450^{\circ} \mathrm{C}, 2 \mathrm{~h}\right) \mathrm{GF} / \mathrm{F}$ filters. Due to the number of treatments, replication was not possible. However, routine analyses conducted with the same protocols and on the same instrumentation yielded an average variation in ${ }^{15} \mathrm{~N}$ isotope enrichment of $<0.5 \%$ in replicated samples (Glibert et al. 2006). The uptake rates of $\mathrm{NO}_{3}{ }^{-}$were not measured after May 28, due to limited supply of this isotope. 
To evaluate the possibility of $\mathrm{P}$ limitation, some experiments were also conducted on samples that were enriched with $\mathrm{PO}_{4}{ }^{3-}$ to $3 \mu \mathrm{mol} \mathrm{P} \mathrm{l^{-1 }}$ and pre-incubated for either $2 \mathrm{~h}$ or overnight before the start of the ${ }^{15} \mathrm{~N}$ enrichment experiments.

All GF/F filters for isotope analysis were dried for $24 \mathrm{~h}$ at $50^{\circ} \mathrm{C}$ and were analyzed for isotope enrichment using a Sercon mass spectrometer. Rates of ${ }^{15} \mathrm{~N}$ uptake were calculated according to Glibert \& Capone (1993).

Data analysis. One-way ANOVA, $t$-test and paired $t$-test analyses were conducted to compare the nutrient data in different phases of the blooms and to compare and contrast uptake rates with the P-enriched treatments.

\section{RESULTS}

\section{Overview}

The cruise time series covered a succession of phytoplankton species. No dinoflagellate blooms were observed during the first cruise (April 23 to May 18), although the presence of dinoflagellates was noted in the phytoplankton community, which was dominated by diatoms during this period (Chiang et al. 1999). However, beginning with the first day of the second cruise (May 25), Karenia mikimotoi was observed to dominate the assemblages in all transects (maximum $8 \times 10^{6}$ cells $1^{-1}$ at Station za-1). The total area of the K. mikimotoi blooms was ultimately estimated to be over $15000 \mathrm{~km}^{2}$. The K. mikimotoi blooms were also associated with a massive fish kill when the blooms reached the coastal aquaculture areas. High-value aquaculture fish (Sciaenops ocellatus, Miichthys miiuy, Epinephelus spp., Monotaxis grandoculis) worth about
$\$ 2.5$ million were lost due to this bloom. $K$. mikimotoi blooms were succeeded by Prorocentrum donghaiense (maximum $5 \times 10^{6}$ cells $1^{-1}$ at Station ra-1) from the second week of June on. The dinoflagellate blooms were observed to be in the decay phase during the third cruise. Noctiluca scintillans was a common species observed throughout the cruises, and the biomass of $N$. scintillans (not shown) was highest after the blooms of $K$. mikimotoi and $P$. donghaiense, when orangecolored surface patches could be observed.

\section{Ambient parameter comparisons}

A total of 47 surface water samples and 32 subsurface $(10 \mathrm{~m})$ water samples from the 3 cruises were analyzed for nutrient concentrations. The sample period covered the time series before the blooms, and during the Karenia mikimotoi and the Prorocentrum donghaiense blooms. Therefore, the sample periods were categorized according to the different phases of the blooms - I: before blooms (May 5 to 14 ); II: early $K$. mikimotoi blooms (May 26 to 31); III: late K. mikimotoi blooms (June 2 to 4); IV: early $P$. donghaiense blooms (June 9 to 12); and V: late P. donghaiense blooms (June 15 to 24). When comparing sub-surface data, bloom phases were combined as II + III: K. mikimotoi blooms and IV + V: P. donghaiense blooms.

$\mathrm{TN}$ in the water column decreased significantly during bloom progression (Table 1, Fig. 2; p < 0.005). TN concentration in surface water decreased from an average of $31 \mu \mathrm{mol} \mathrm{N} l^{-1}$ in Phase I to $<16 \mu \mathrm{mol} \mathrm{N}{ }^{-1}$ in Bloom Phases III and IV. Concentrations in sub-surface water also decreased from $30 \mu \mathrm{mol} \mathrm{N}{ }^{-1}$ in Phase I to

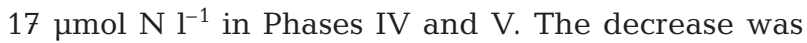
mostly the result of depletion of $\mathrm{NO}_{3}{ }^{-} \cdot \mathrm{NO}_{3}{ }^{-}$, which

Table 1. Ambient nutrients in the East China Sea during the spring of 2005. Values shown are averages for the bloom period and depth indicated. Values for $\mathrm{NO}_{3}{ }^{-}, \mathrm{NH}_{4}{ }^{+}$, urea, dissolved free amino acid (DFAA), total nitrogen (TN), particulate organic nitrogen

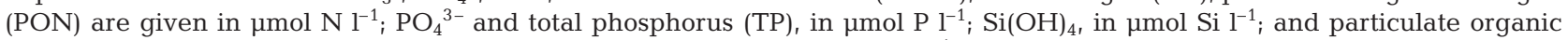
carbon (POC), in $\mu \mathrm{mol} \mathrm{C} \mathrm{^{-1 }}$

\begin{tabular}{|c|c|c|c|c|c|c|c|c|c|c|}
\hline & $\mathrm{NO}_{3}^{-}$ & $\mathrm{NH}_{4}^{+}$ & Urea & DFAA & $\mathrm{PO}_{4}^{3-}$ & $\mathrm{Si}(\mathrm{OH})_{4}$ & $\mathrm{TN}$ & $\mathrm{TP}$ & PON & POC \\
\hline \multicolumn{11}{|c|}{ Cruise I: April 23-May 18 pre-blooms } \\
\hline Surface & 18.8 & 0.95 & 0.38 & 0.24 & 0.35 & 17.4 & 30.5 & 0.78 & 4.3 & 35.1 \\
\hline $10 \mathrm{~m}$ & 17.2 & 0.85 & 0.41 & 0.18 & 0.31 & 19.8 & 27.4 & 0.64 & 4.0 & 32.5 \\
\hline \multicolumn{11}{|c|}{ Cruise II: May 25-June 7 Karenia mikimotoi bloom } \\
\hline Surface & 7.2 & 1.0 & 0.71 & 0.78 & 0.20 & 24.2 & 20.4 & 0.56 & 20.4 & 161.5 \\
\hline $10 \mathrm{~m}$ & 8.4 & 1.51 & 0.52 & 0.26 & 0.18 & 18.1 & 20.9 & 0.50 & 7.6 & 55.2 \\
\hline \multicolumn{11}{|c|}{ Cruise II: June 8-19 Prorocentrum donghaiense bloom } \\
\hline Surface & 3.0 & 1.3 & 1.45 & 1.1151 & 0.21 & 23.9 & 17.8 & 0.51 & 13.8 & 101.2 \\
\hline $10 \mathrm{~m}$ & 5.27 & 1.13 & 0.85 & 0.40 & 0.15 & 22.1 & 16.9 & 0.34 & 12.7 & 89.8 \\
\hline \multicolumn{11}{|c|}{ Cruise III: June 22-25 late blooms } \\
\hline Surface & 3.7 & 1.62 & 1.31 & 0.75 & 0.68 & 16.4 & 33.0 & 1.34 & 9.4 & 68.3 \\
\hline $10 \mathrm{~m}$ & 4.8 & 3.08 & 1.03 & 0.48 & 0.25 & 12.6 & 17.3 & 0.16 & 6.4 & 46.6 \\
\hline
\end{tabular}


Fig. 2. Concentrations of the measured forms of dissolved nitrogen, phosphorus and silicate in the water column in the bloom time series in surface waters (S) and sub-surface waters (around $10 \mathrm{~m}$ depth, D) during different phases of blooms-I: before blooms; II: early Karenia mikimotoi blooms; III: late $K$. mikimotoi blooms; IV: early Prorocentrum donghaiense blooms; V: late $P$. donghaiense blooms; II + III: $K$. mikimotoi blooms; IV + V: P. donghaiense blooms; TN: total dissolved nitrogen; DON: dissolved organic nitrogen; DFAA: dissolved free amino acid; DIP: dissolved inorganic phosphorus; DOP: dissolved organic phosphorus; (O): data from the sub-surface water; (৩): data from the surface water; (----): trend line of sub-surface water; (-): trend line of surface data. Box plots-line: median; box: 25th and 75th percentiles; whiskers: 10 th and 90th percentiles; dots: outliers. ${ }^{*} \mathrm{p}<$ $0.05 ;{ }^{* *} \mathrm{p}<0.005 ;{ }^{* * *} \mathrm{p}<0.0005$

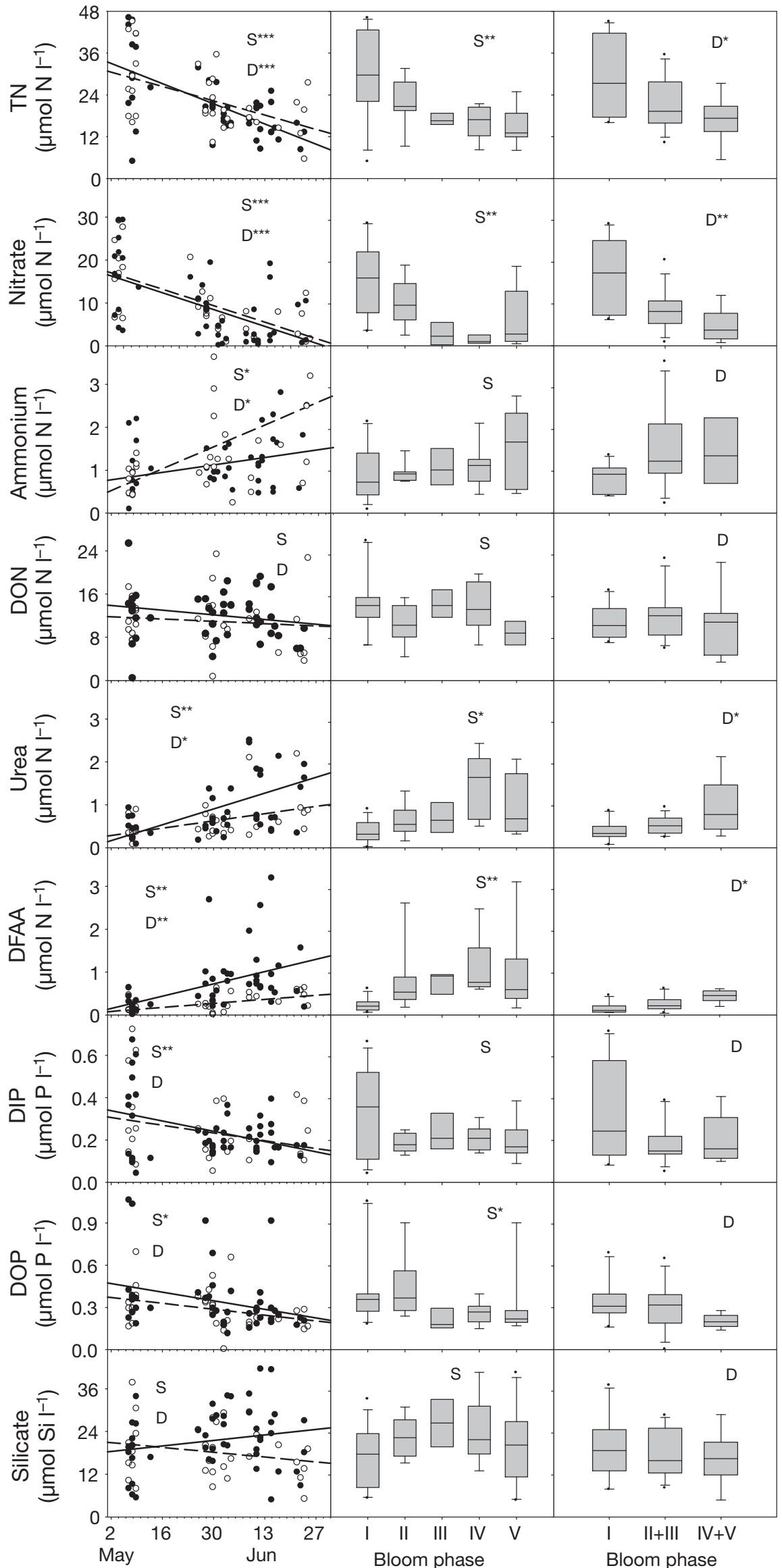



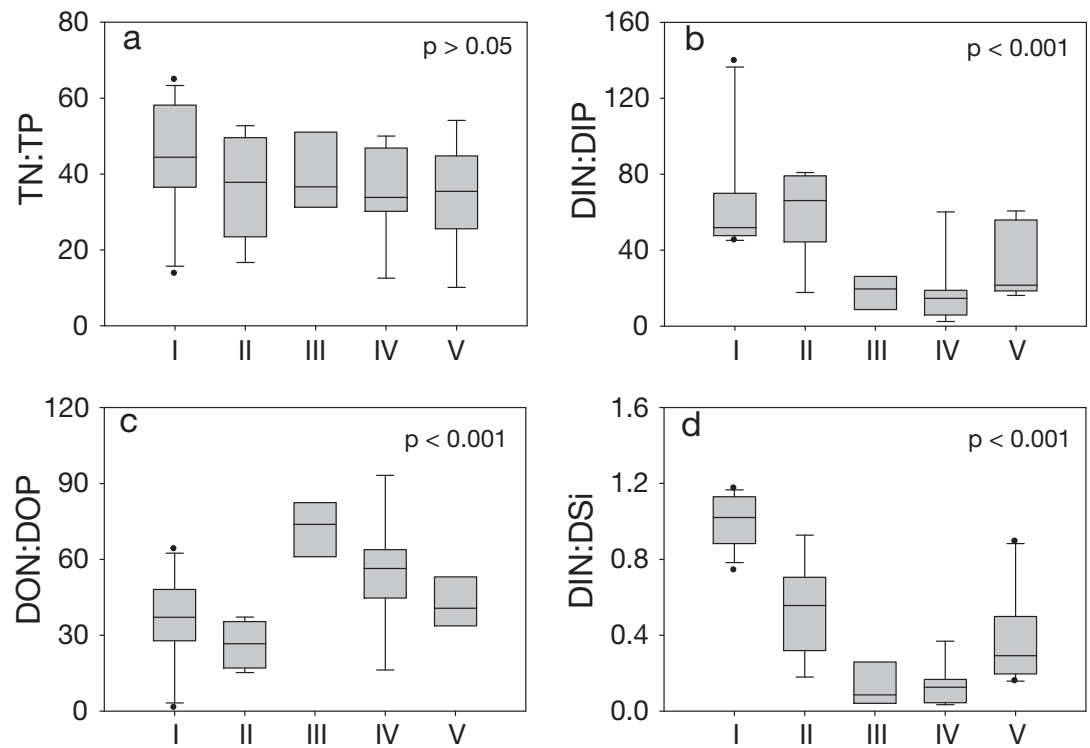

Fig. 3. The molar ratio of dissolved nitrogen to phosphorus and silicate in the water column in the bloom time series in surface water during different phases of blooms-I: before blooms; II: early Karenia mikimotoi blooms; III: late K. mikimotoi blooms; IV: early Prorocentrum donghaiense blooms; V: late P. donghaiense blooms; TN: total dissolved nitrogen; TP: total dissolved phosphorus; DIN: dissolved inorganic nitrogen; DIP: dissolved inorganic phosphorus; DOP: dissolved organic phosphorus; DON: dissolved organic nitrogen; DSi: dissolved silicate. Box plots - line: median; box: 25th and 75th percentiles; whiskers: 10th and 90th percentiles; dots: outliers.

contributed $>55 \%$ to the TN pool before the bloom, became depleted significantly during bloom progression (Table 1, Fig. 2; p < 0.005). The average surface $\mathrm{NO}_{3}{ }^{-}$concentration decreased from $18.8 \mu \mathrm{mol} \mathrm{N}^{-1}$ in Phase I to $2 \mu \mathrm{mol} \mathrm{N}{ }^{-1}$ in Phases III and IV, but recovered slightly to $7 \mu \mathrm{mol} \mathrm{N} \mathrm{^{-1 }}$ in Phase $\mathrm{V}_{\text {; }}$ sub-surface $\mathrm{NO}_{3}{ }^{-}$concentration also decreased from 18 to $5 \mu \mathrm{mol}$ $\mathrm{N} \mathrm{l}^{-1}$. During the late bloom period, $\mathrm{NO}_{3}^{-}$only contributed $<10 \%$ of the TN pool at most stations.

In contrast to $\mathrm{NO}_{3}{ }^{-}$, reduced $\mathrm{N}\left(\mathrm{NH}_{4}^{-}\right.$, urea, and DFAA) did not decrease, but rather increased significantly throughout the time series (Table 1, Fig. $2 ; \mathrm{p}<$ 0.05). Comparing Phase I and IV in the surface water, $\mathrm{NH}_{4}{ }^{+}$increased from 1 to $1.5 \mu \mathrm{mol} \mathrm{N} \mathrm{l}{ }^{-1}$, urea increased

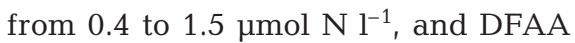
increased from 0.2 to $1.1 \mu \mathrm{mol} \mathrm{N} \mathrm{l}{ }^{-1}$. In sub-surface water, $\mathrm{NH}_{4}^{+}$increased

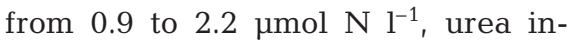
creased from 0.4 to $1 \mu \mathrm{mol} \mathrm{N} \mathrm{l}^{-1}$, and DFAA increased from 0.15 to $0.44 \mu \mathrm{mol}$ $\mathrm{N}^{-1}$. DON remained relatively constant at around $12 \mu \mathrm{mol} \mathrm{N}^{-1}$ in surface

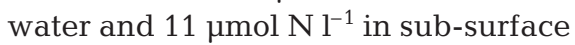
water (Fig. 2). However, the percentage of DON in the TN pools in surface water increased from an average of $42 \%$ in Phase I to $62 \%$ in Phases II and III, and $77 \%$ in Phases IV and V.

The average DIP concentration in surface water decreased significantly from about $0.35 \mu \mathrm{mol} \mathrm{P}{ }^{-1}$ in Phase I to $0.19 \mu \mathrm{mol} \mathrm{P}{ }^{-1}$ after the blooms developed (Fig. $2 ;$ p < 0.05). DOP in surface water decreased significantly from 0.43 to about $0.2 \mu \mathrm{mol} \mathrm{P} \mathrm{l}^{-1}$ (Fig. 2 ; $\mathrm{p}<$ 0.05). However, DIP and DOP in the sub-surface water remained constant. The contribution of DIP to TP also remained constant at around $40 \%$. Average $\mathrm{Si}(\mathrm{OH})_{4}$ concentrations were around $20 \mu \mathrm{mol} \mathrm{Si} \mathrm{l}^{-1}$ throughout the time series (Fig. 2).

There was no significant variation in the TN:TP ratio during bloom progression (Fig. 3a), and TN:TP ratios were around 40 ; however the ratios of organic and inorganic compounds varied significantly $(\mathrm{p}<0.001)$. Average molar DIN $\left(\mathrm{NO}_{3}{ }^{-}+\mathrm{NO}_{3}{ }^{-}+\mathrm{NH}_{4}{ }^{+}\right)$: DIP $\left(\mathrm{PO}_{4}{ }^{3-}\right)$ ratios were about 65 in Phase I, which was much higher than the Redfield ratio (16:1), and even higher in Phase II. Then, DIN:DIP ratios decreased after the Karenia mikimotoi blooms developed, declined to an average of 22 in Phase III, and declined even further in Phase IV. The DIN:DIP ratio rose to $\sim 33$ during the declining bloom (Phase V) (Fig. 3b, Table 2). In contrast, the average molar DON:DOP ratio showed the opposite pattern, with ratios remaining at $<40$ in

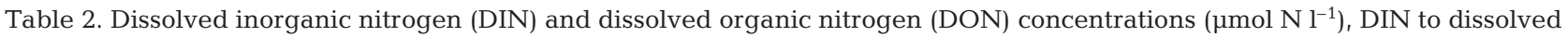
inorganic phosphate (DIP) ratio, DON to dissolved organic phosphate (DOP) ratio, and DIN to dissolved silicate $\left(\mathrm{Si}[\mathrm{OH}]_{4}\right)$ ratio in different phases of the bloom series -I: before blooms; II: early Karenia mikimotoi blooms; III: late K. mikimotoi blooms; IV: early Prorocentrum donghaiense blooms; V: late $P$. donghaiense blooms

\begin{tabular}{|c|c|c|c|c|c|c|c|c|c|c|}
\hline \multirow[t]{2}{*}{ Phas } & \multicolumn{2}{|c|}{ 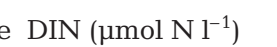 } & \multicolumn{2}{|c|}{$\mathrm{DON}\left(\mu \mathrm{mol} \mathrm{N} \mathrm{l^{-1 } )}\right.$} & \multicolumn{2}{|c|}{ DIN:DIP } & \multicolumn{2}{|c|}{ DON:DOP } & \multicolumn{2}{|c|}{$\mathrm{DIN}: \mathrm{Si}(\mathrm{OH})_{4}$} \\
\hline & Surface & $10 \mathrm{~m}$ & Surface & $10 \mathrm{~m}$ & Surface & $10 \mathrm{~m}$ & Surface & $10 \mathrm{~m}$ & Surface & $10 \mathrm{~m}$ \\
\hline I & $17.4 \pm 8.5$ & $18.0 \pm 8.4$ & $13.2 \pm 6.4$ & $11.2 \pm 3.4$ & $65.9 \pm 31.2$ & $65.1 \pm 19.8$ & $36.3 \pm 17.6$ & $36.8 \pm 14.1$ & $1.0 \pm 0.13$ & $0.92 \pm 0.23$ \\
\hline II & $11.3 \pm 5.3$ & $12.1 \pm 3.8$ & $10.7 \pm 3.6$ & $11.5 \pm 6.8$ & $60.7 \pm 22.2$ & $74.8 \pm 26.3$ & $26.1 \pm 8.6$ & $26.9 \pm 12.1$ & $0.50 \pm 0.24$ & $0.72 \pm 0.26$ \\
\hline III & $3.3 \pm 2.6$ & $4.6 \pm 2.8$ & $13.7 \pm 3.4$ & $11.8 \pm 2.5$ & $17.8 \pm 9.9$ & $31.3 \pm 24.6$ & $69.7 \pm 18.6$ & $58.3 \pm 44.0$ & $0.13 \pm 0.12$ & $0.32 \pm 0.28$ \\
\hline IV & $3.0 \pm 2.5$ & $5.4 \pm 2.8$ & $13.4 \pm 4.2$ & $12.28 \pm 0.9$ & $11.1 \pm 6.77$ & $36.5 \pm 10.6$ & $54.7 \pm 20.6$ & $64.0 \pm 6.4$ & $0.12 \pm 0.10$ & $0.23 \pm 0.08$ \\
\hline $\mathrm{V}$ & $7.7 \pm 6.5$ & $8.2 \pm 4.4$ & $9.5 \pm 3.6$ & $8.6 \pm 7.2$ & $32.7 \pm 18.9$ & $37.5 \pm 18.9$ & $42.1 \pm 11.4$ & $27.2 \pm 11.3$ & $0.39 \pm 0.24$ & $0.61 \pm 0.30$ \\
\hline
\end{tabular}


Phase I and decreasing to around 20 when blooms developed in Phase II. However, the ratio increased significantly to about 70 in Phases III and IV. The DON:DOP ratio only declined when blooms decayed (Fig. 3c, Table 2).

The average DIN:Si $(\mathrm{OH})_{4}$ ratios decreased significantly from $\sim 1.0$ to $\sim 0.4$ when a bloom developed ( $\mathrm{p}<$ 0.005), and further decreased to $\sim 0.17$ in Phases III and IV. Finally, DIN:Si(OH) $)_{4}$ increased to 0.42 in Phase V (Fig. 3f, Table 2).
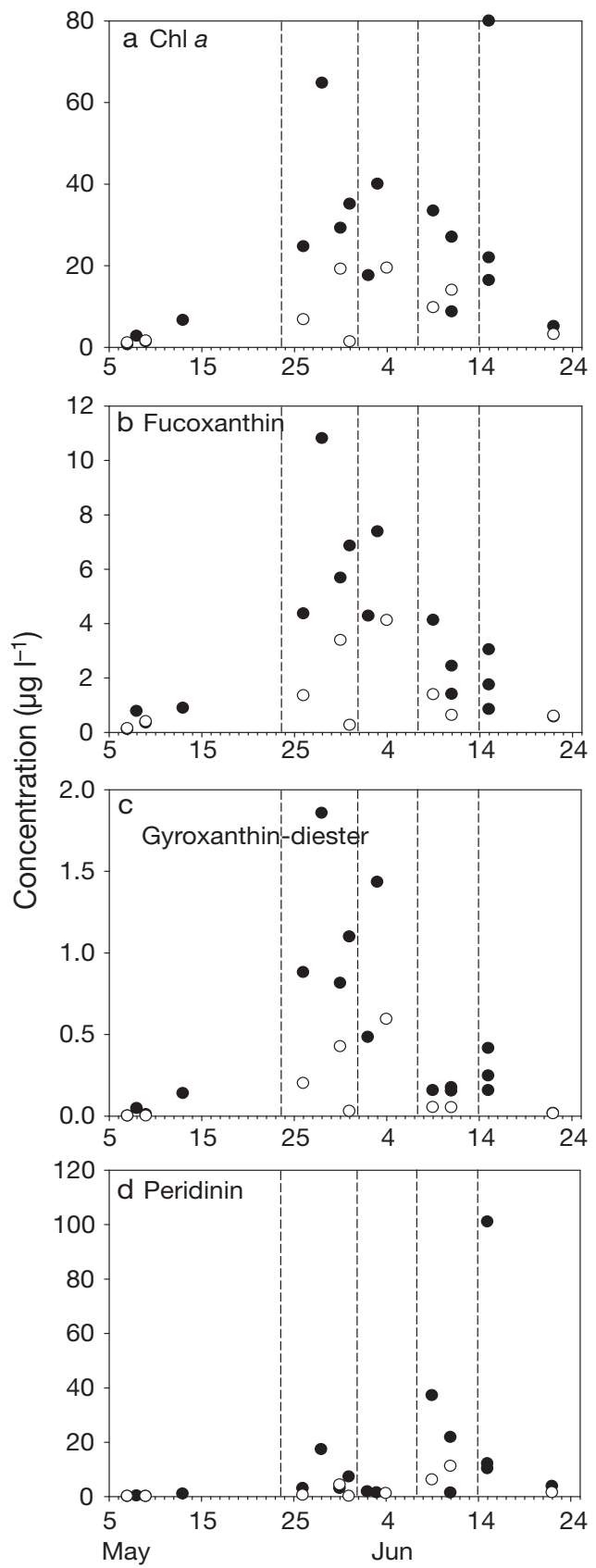

\section{Pigment concentrations and phytoplankton composition}

In early May, total chl a concentrations, on average, were low $\left(\sim 1.5 \mathrm{~g} \mathrm{I} \mathrm{l}^{-1}\right)$ in both surface and $10 \mathrm{~m}$ samples. A higher chl a concentration $\left(\sim 7.5 \mu \mathrm{g} \mathrm{l^{-1 } )}\right.$ was observed on May 13 before the end of the first cruise. Significantly higher chl a concentrations developed during the dinoflagellate blooms ( $<<0.05)$ : $65 \mu \mathrm{g} \mathrm{l}^{-1}$ in Phase II and $80 \mu \mathrm{g} \mathrm{l}^{-1}$ in Phase IV (Fig. 4a). The
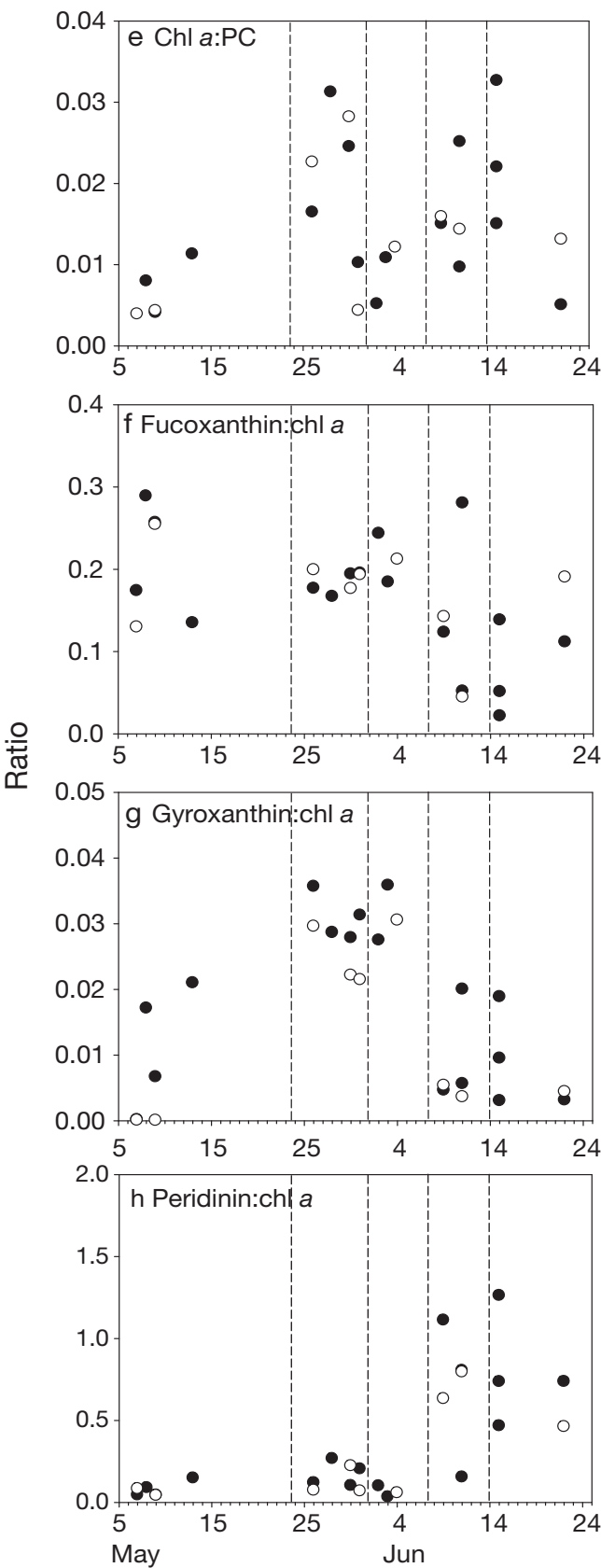

Fig. 4. (a) Chlorophyll a (chl a) concentration $\left(\mu \mathrm{g} \mathrm{l} \mathrm{l}^{-1}\right)$; (e) chl a:particulate carbon (PC) ratio in the water column; concentrations of the pigments (b) fucoxanthin, (c) gyroxanthin-diester, and (d) peridinin $\left(\mu \mathrm{g} \mathrm{l}^{-1}\right)$; and the ratios of (f) fucoxanthin:chl a (g) gyroxanthin-diester:chl $a$ and $(\mathrm{h})$ peridinin:chl $a$ in the water column in the bloom time series. (O): data from subsurface water; (0): data from surface water; vertical lines indicate the transitions between bloom phases 
chl a:particulate carbon (PC) ratios also increased significantly during the bloom succession (Fig. 4e, p < 0.05).

Concentrations of the 3 indicator pigments showed a trend increasing from a low value, reaching a significantly high peak and finally decaying in both surface water and sub-surface water $(p<0.05)$. Fucoxanthin and gyroxanthin-diester reached their maximum values in Phase II, while peridinin reached its maximum value in Phase V (Fig. 4b,c,d). Concentrations of these pigments in the surface water were significantly higher than in the sub-surface water $(p<0.05)$. The relative abundance of the indicator pigments also showed different trends during bloom succession. The
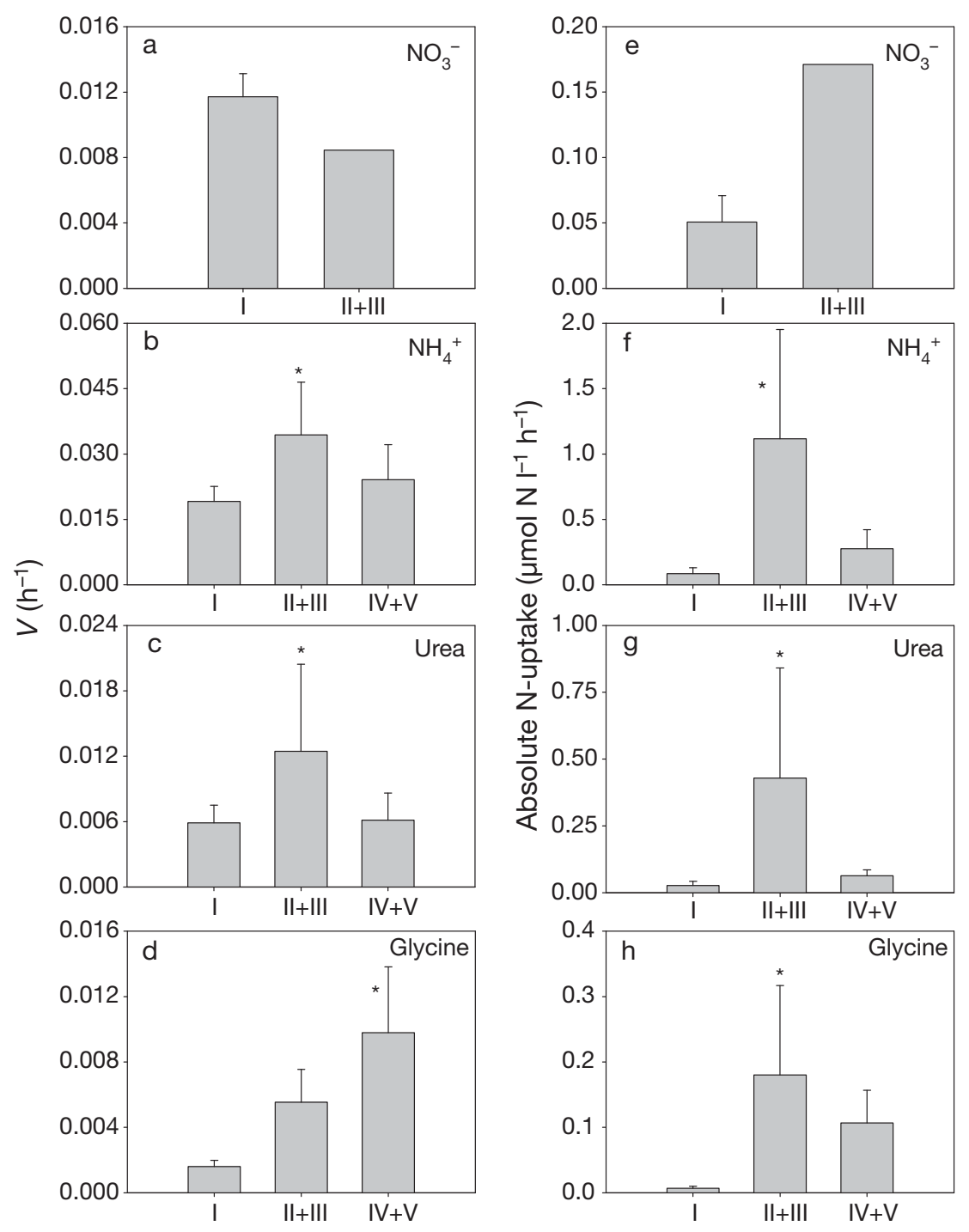

Fig. 5. (a,b,c,d) N-specific uptake rates $V\left(\mathrm{~h}^{-1}\right)$ and $(\mathrm{e}, \mathrm{f}, \mathrm{g}, \mathrm{h})$ absolute $\mathrm{N}$-uptake

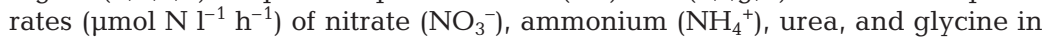
the bloom time series. No nitrate data are available after May 28. I: Before blooms; II + III: Karenia mikimotoi blooms; IV + V Prorocentrum donghaiense blooms; ${ }^{*} \mathrm{p}<0.05$; error bars: SD relative abundance of fucoxanthin:chl a decreased significantly throughout the study ( $p<0.05$, Fig. 4f), while the relative abundance of gyroxanthin-diester: chl a reached its peak during the midpoint of the time series (in Phases II and III; Fig. 4g), and peridinin:chl $a$ increased later (in Phases IV and $V_{i}$ not shown).

\section{Nitrogen uptake experiments}

The $\mathrm{N}$-specific uptake rates $\left(V, \mathrm{~h}^{-1}\right)$ of $\mathrm{NO}_{3}^{-}$varied between $0.008 \mathrm{~h}^{-1}$ at an ambient $\mathrm{NO}_{3}^{-}$of $2.6 \mu \mathrm{mol} \mathrm{N}{ }^{-1}$ and $0.013 \mathrm{~h}^{-1}$ at an ambient $\mathrm{NO}_{3}{ }^{-}$of $6.2 \mu \mathrm{mol} \mathrm{N} \mathrm{l}{ }^{-1}$ (Fig. $5 a)$. Due to the variation of biomass in the water column, absolute uptake rates of $\mathrm{NO}_{3}{ }^{-}$



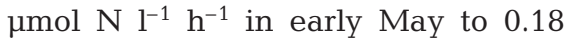

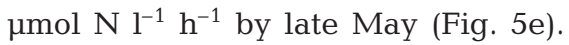
$\mathrm{NO}_{3}{ }^{-}$contributed about $30 \%$ of the total $\mathrm{N}$ uptake (sum of the uptake rates of $\mathrm{NO}_{3}{ }^{-}, \mathrm{NH}_{4}{ }^{+}$, urea, and glycine) before the period of dinoflagellate dominance and decreased to $<20 \%$ of total $\mathrm{N}$ uptake after these blooms had become established, after which rates of $\mathrm{NO}_{3}{ }^{-}$were not measured.

The rates of uptake of reduced $\mathrm{N}$ also varied with the bloom progression (Fig. 5b,c,d,f,g,h). The Nspecific uptake rates of $\mathrm{NH}_{4}{ }^{+}$were between $0.016 \mathrm{~h}^{-1}$ at an ambient $\mathrm{NH}_{4}{ }^{+}$of $0.63 \mathrm{mmol} \mathrm{l}^{-1}$ and $0.043 \mathrm{~h}^{-1}$ at an ambient $\mathrm{NH}_{4}{ }^{+}$of $1.59 \mu \mathrm{mol} \mathrm{l}^{-1}$, and were significantly higher in Phases II and III than in Phase I $(p<0.05)$. Absolute uptake rates of $\mathrm{NH}_{4}{ }^{+}$increased from $0.06 \mu \mathrm{mol} \mathrm{l}^{-1} \mathrm{~h}^{-1}$ in Phase I to a maximum rate of $1.71 \mu \mathrm{mol} \mathrm{l}^{-1} \mathrm{~h}^{-1}$ in Phase II and decreased to $0.18 \mu \mathrm{mol} \mathrm{l}^{-1} \mathrm{~h}^{-1}$ in Phase III. Overall, $\mathrm{NH}_{4}{ }^{+}$contributed an average of $66 \%$ of the total reduced $\mathrm{N}$ uptake (sum of the uptake rates of $\mathrm{NH}_{4}^{+}$, urea, and glycine) throughout the time series.

Urea contributed, on average, $20 \%$ of the total reduced $\mathrm{N}$ uptake. Rates of urea uptake were significantly higher on both an $\mathrm{N}$-specific and absolute basis in Phases II and III than in Phase I (Fig. 5c,g; p < 0.05). Potential rates of glycine uptake increased during the bloom succession, and were significantly higher in Phases IV and V $(p<0.05)$, as was the percent contribution of this $\mathrm{N}$ sub- 


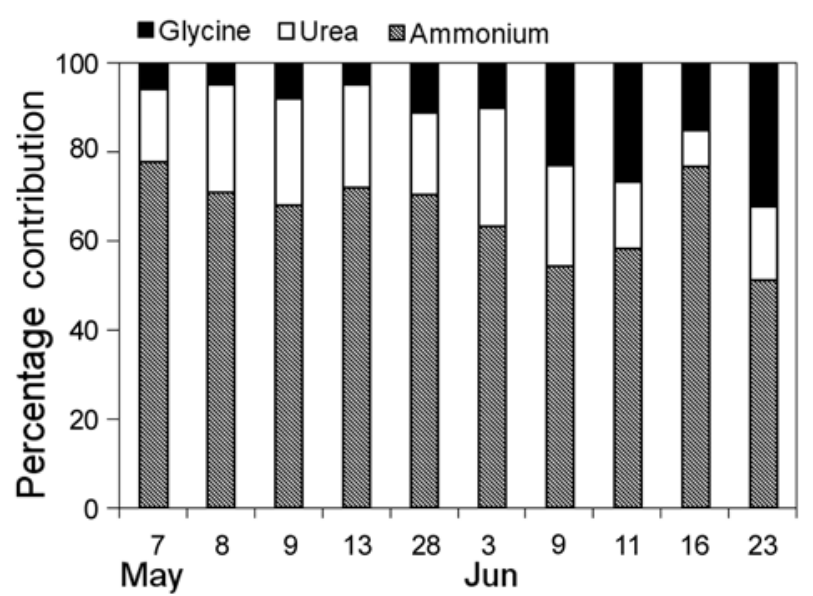

Fig. 6. The relative contribution of reduced $\mathrm{N}$ (ammonium $\left[\mathrm{NH}_{4}{ }^{+}\right]$, urea, and glycine) to total reduced $\mathrm{N}$-uptake rates in the bloom time series

strate to total $\mathrm{N}$ uptake. Assuming that DFAA concentrations were representative of glycine availability, a maximum assumption, glycine uptake represented only about $5 \%$ of total reduced $\mathrm{N}$ in Phase I, but its relative (maximal) contribution increased to $11 \%$ in Phases II and III and to $25 \%$ in Phases IV and V (Fig. 6). Higher reduced N-uptake rates were geographically located at both the south stations and the stations close to the mouth of the Changjiang River (Fig. 7).

The relative preference index (RPI) defines the preference of a particular form of $\mathrm{N}$ relative to its availability (McCarthy et al. 1977). For example, for $\mathrm{NH}_{4}{ }^{+}$:

$$
\mathrm{RPI}_{\mathrm{NH}_{4}}=\frac{V_{\mathrm{NH}_{4}}}{\sum V} / \frac{\left[\mathrm{NH}_{4}\right]}{\sum[\mathrm{N}]}
$$

where $V_{\mathrm{NH} 4}$ and $\Sigma V$ are the $\mathrm{N}$-specific uptake rates $\left(\mathrm{h}^{-1}\right)$ of $\mathrm{NH}_{4}{ }^{+}$and total $\mathrm{N}$, and $\left[\mathrm{NH}_{4}\right]$ and $\Sigma[\mathrm{N}]$ are the concentrations of the $\mathrm{NH}_{4}^{+}\left(\mu \mathrm{mol} \mathrm{N} \mathrm{^{-1 }}\right)$ and total $\mathrm{N}$ sources. Values $>1$ represent preference for a particular $\mathrm{N}$ form.

Due to the fact that $\mathrm{NO}_{3}{ }^{-}$uptake rates were not measured after the first cruise, the RPI was calculated in 2 ways. For the first cruise, the 4 different $\mathrm{N}$ sources $\left(\mathrm{NO}_{3}{ }^{-}, \mathrm{NH}_{4}{ }^{+}\right.$, urea, and glycine) were compared. For all cruises, a separate calculation was done for the reduced $\mathrm{N}$ sources $\left(\mathrm{NH}_{4}{ }^{+}\right.$, urea, and glycine) only. Before the dinoflagellate blooms, including at the beginning of Karenia mikimotoi blooms, the RPIs for $\mathrm{NO}_{3}{ }^{-}$were all <0.5. During this same period, the RPIs for $\mathrm{NH}_{4}{ }^{+}$and urea were all $>1$ (Fig. 8a). The RPIs for reduced $\mathrm{N}$ only for the entire time series generally converged on 1 . However, RPIs for urea were $>1$ during the $K$. mikimotoi blooms, but $<1$ during the Prorocentrum donghaiense blooms. The RPIs of glycine

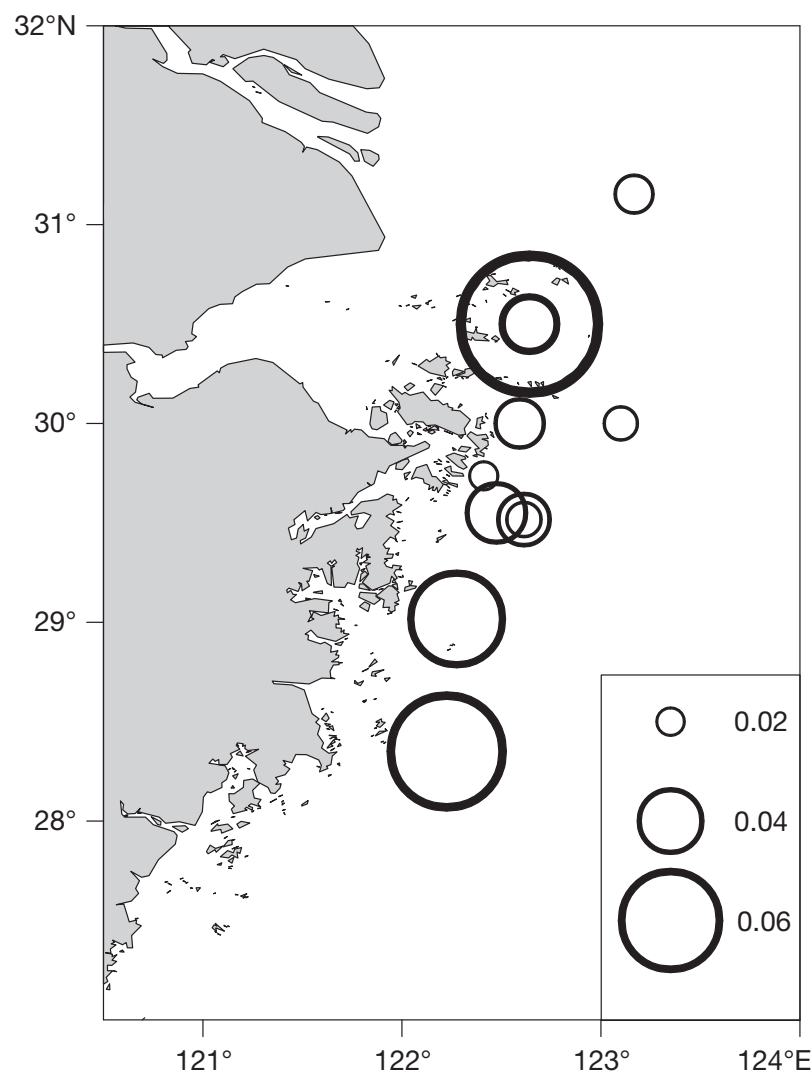

Fig. 7. Geographical results of specific uptake rates of reduced nitrogen $\left(V, \mathrm{~h}^{-1}\right)$ in the bloom area

showed the opposite trend (Fig. 8b). Again, glycine uptake likely represents potential, rather than in situ rates.

\section{Effect of phosphate pre-enrichment}

Pre-enrichment with $\mathrm{P}$ increased the rates of $\mathrm{N}$ uptake in virtually all experiments (Fig. 9). $\mathrm{NO}_{3}{ }^{-}$ uptake rates increased, on average, by $28 \%$, with a maximum increase of $60 \%$. Rates of reduced $\mathrm{N}\left(\mathrm{NH}_{4}{ }^{+}\right.$, urea, and glycine) increased, on average, by $10 \%$, with a maximum increase of $31 \%$. The percentage increase of reduced $\mathrm{N}$-uptake rates is significant ( $\mathrm{p}<0.05)$. Stations close to the Zhoushan Archipelago had the highest percentage increases in rates of reduced $\mathrm{N}$ uptake with P pre-enrichment. The increases were less at the southern stations and off-shore (Fig. 10). On May 28, $\mathrm{N}$-uptake rates with $\mathrm{PO}_{4}{ }^{3-}$ pre-enrichment were compared for samples incubated with $\mathrm{P}$ for $2 \mathrm{~h}$ and overnight before $\mathrm{N}$-uptake rates were measured. The longer incubation time with $\mathrm{P}$ enrichment yielded a significantly greater increase in $\mathrm{N}$ uptake $(\mathrm{p}<0.05$; Fig. 11). 


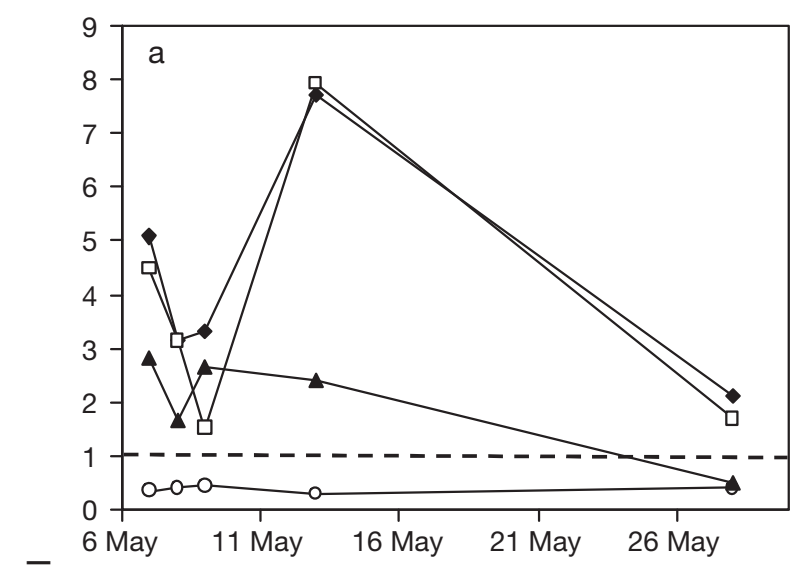

$\bar{n}$

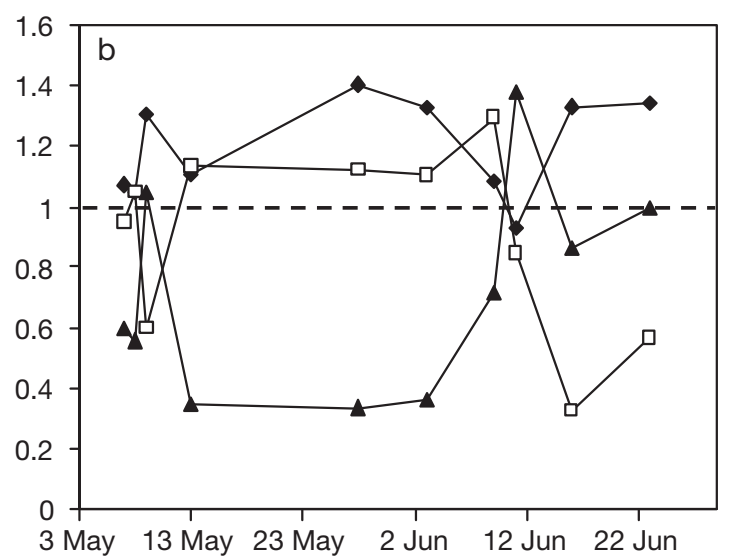

Fig. 8. Relative preference index (RPI) for the uptake of different $\mathrm{N}$ sources. (a) RPI values calculated using $\mathrm{NO}_{3}^{-}(\mathrm{O}), \mathrm{NH}_{4}{ }^{+}$ $(\bullet)$, urea $(\square)$, and glycine $(\boldsymbol{\Delta})$ for the period of the time series up to the beginning of the Karenia mikimotoi blooms. (b) RPI values calculated using only $\mathrm{NH}_{4}{ }^{+}(\diamond)$, urea $(\square)$, and glycine $(\boldsymbol{\Lambda})$ for the entire time series

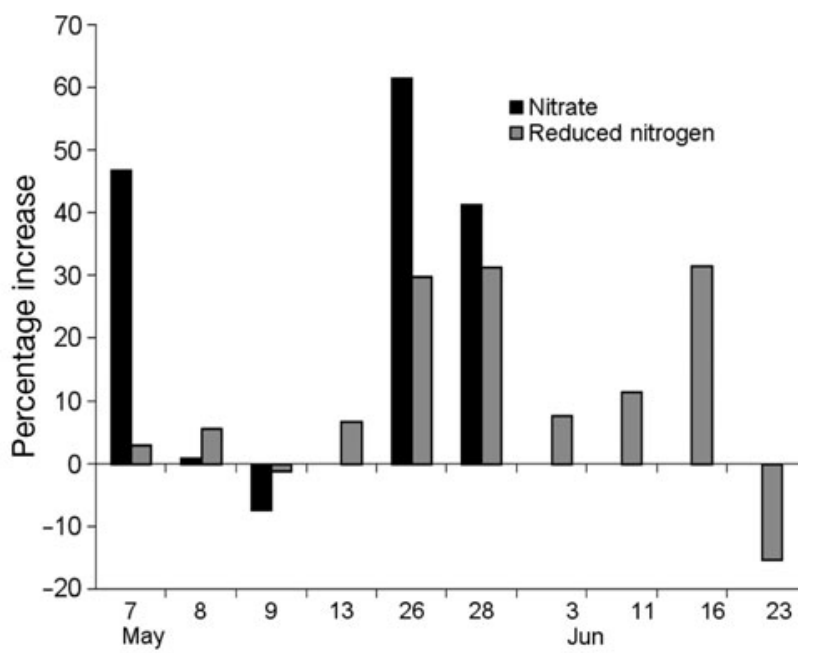

Fig. 9. Percent increase in the rate of $\mathrm{NO}_{3}{ }^{-}$and reduced nitrogen forms (the sum of $\mathrm{NH}_{4}{ }^{+}$, urea, and glycine) after phosphorus enrichment for $2 \mathrm{~h}$ for the date shown

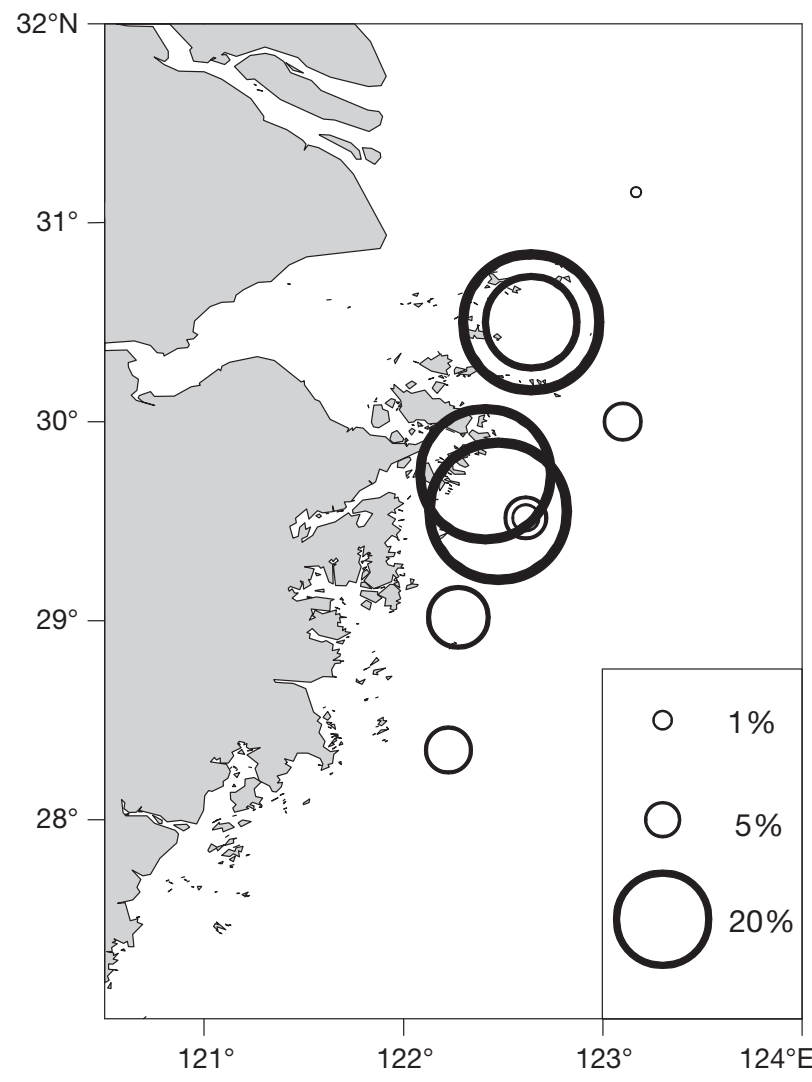

Fig. 10. Spatial variation in the percent increase in the rate of reduced $\mathrm{N}$ uptake (the sum of $\mathrm{NH}_{4}{ }^{+}$, urea, and glycine) after phosphorus enrichment for $2 \mathrm{~h}$ in the bloom area from samples collected on different days

\section{DISCUSSION}

\section{Overview}

The dinoflagellate blooms in the coastal area of the ECS in 2005 were large (>15000 km²) and exhibited a unique succession of species compared to events in the previous years (Tang et al. 2006). Here, the results on nutrient concentrations and $\mathrm{N}$-uptake rates are placed in the context of bloom succession. In addition, comparisons of $\mathrm{N}$-uptake rates and molar ratios are made with a system that experiences similar diatom and dinoflagellate blooms, i.e. the southwestern Florida Shelf, Gulf of Mexico (Heil et al. 2007).

\section{Bloom succession, nutrient availability, and molar $\mathrm{N}: \mathrm{P}$ ratios}

In late April in the ECS, before dinoflagellates became dominant, both DIN and $\mathrm{PO}_{4}{ }^{3-}$ concentrations decreased gradually seaward from the CJRE, suggesting terrestrial sources of $\mathrm{N}$ and $\mathrm{P}$ at this time. During 

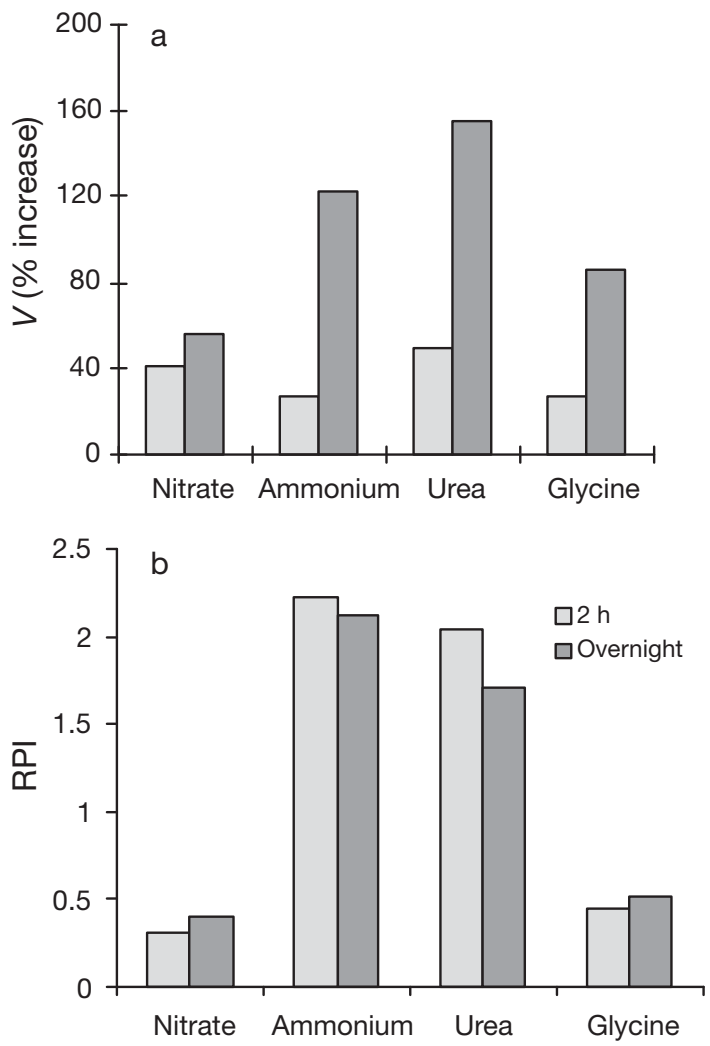

Fig. 11. (a) The percentage increase in $\mathrm{N}$-specific uptake rates $V\left(\mathrm{~h}^{-1}\right)$ and (b) the relative preference index (RPI). Sample water was pre-incubated with $3 \mu \mathrm{M} \mathrm{PO}_{4}{ }^{3-}$ for $2 \mathrm{~h}$ and for $12 \mathrm{~h}$ (overnight) on May 28, 2005 at a station near Station ra-1. Dissolved inorganic nitrogen:dissolved inorganic phosphorus $(\mathrm{DIN}: \mathrm{DIP})=17.7$

this period, although both $\mathrm{N}$ and $\mathrm{P}$ appeared to be land derived, N was considerably higher than $\mathrm{P}$, leading to a high ambient molar ratio of DIN:DIP ( 65). Skeletonema costatum was the dominant species, and cell densities of up to $10^{7}$ cells $\mathrm{l}^{-1}$ were recorded (Chiang et al. 1999). Spring diatom blooms in the early spring in the ECS have been recorded in this area since the late 20th century (Chiang et al. 1999, 2004, Ishikawa \& Furuya 2004). The water column of the coastal China Sea is well mixed and re-suspended by the winter monsoon and tides and storms in the winter; thus nutrient regeneration and remineralization are assumed to be enhanced during this period. Diatoms are thought to be the major consumers of nutrients that accumulate in these areas in the early spring, as temperatures begin to rise (Ishikawa \& Furuya 2004). Diatoms have been reported to have higher $\mathrm{NO}_{3}{ }^{-}$uptake rates than dinoflagellates at low temperatures (Lomas \& Glibert 2000). S. costatum in nutrient-replete waters, particularly where $\mathrm{NO}_{3}{ }^{-}$is the dominant $\mathrm{N}$ form, is favored and outcompetes Prorocentrum donghaiense at temperatures $<15^{\circ} \mathrm{C}$ (Li et al. 2003, Wang et al. 2006).
In Chesapeake Bay, USA, where diatoms typically comprise 80 to $90 \%$ of the total algal abundance during early spring blooms, both the depletion of $\mathrm{Si}(\mathrm{OH})_{4}$ and $\mathrm{P}$ have been suggested to be responsible for the decay of blooms (Conley \& Malone 1992, Fisher et al. 1992). In Chesapeake Bay, $P$ limitation lasts until more P-replete freshwater input in the summer is delivered, and this period is often associated with frequent blooms of Prorocentrum minimum in the upper and middle Chesapeake Bay (Tango et al. 2005). Our knowledge of the relationships between spring diatom blooms and the later dinoflagellate blooms in the ECS is still limited. However, similar to nutrient dynamics in the Chesapeake Bay, after the spring diatom blooms, a P-limited (DIN:DIP ratio $>60$; Table 2) condition evolves. Increasing river input in late spring in the coastal ECS may result in the delivery of $\mathrm{N}$ into this area; however, due to the relatively low $\mathrm{P}$ concentration in the runoff, additional $\mathrm{P}$ sources are important for dinoflagellate blooms to succeed. The TWWC is a P-replete current; its strength increases in the early spring and could reach the CJRE from the bottom, providing $P$ from this off-shore source (Tang et al. 2000). The suggested role of this P source is supported by the spatial and temporal progression of N:P gradients, showing the decrease in P limitation seaward (Fig. 12).

The dinoflagellate species Prorocentrum donghaiense and Karenia mikimotoi were observed to accumulate around the pycnocline in deeper waters toward the end of our first cruise and reached $10^{3}$ cells $1^{-1}$ (K. mikimotoi). Gyroxanthin-diester, the specific pigment indicator for $K$. mikimotoi, increased when ambient molar DIN:DIP ratios were ca. 60 to 80. Then, as the blooms progressed, the DIN:DIP ratio dropped and, in fact, was ultimately lower than the Redfield ratio by the end of the $K$. mikimotoi dominance period (Table 2). During this progression, the corresponding molar DON:DOP range was ca. 20 to 50. Peridinin, an indicator for $P$. donghaiense, showed a different pattern of association with ambient N:P ratios. Blooms were dominant when ambient DIN:DIP ratios were around 20 and DON:DOP ratios were around 60 (Table 2). This progression suggests that $K$. mikimotoi proportionately depended on DIP and DON. P. donghaiense was more competitive than $K$. mikimotoi at a DIN:DIP ratio of 16 and successfully became the dominant species. The DIN:DIP ratio remained close to the Redfield ratio during the $P$. donghaiense blooms.

Reduced $\mathrm{N}$ forms were preferentially taken up during the blooms. $\mathrm{NH}_{4}{ }^{+}$was always used preferentially relative to its availability, as shown by the RPI calculation (Fig. 8). Urea was most preferred during the Karenia mikimotoi blooms, which suggests that urea was an important DON source for K. mikimotoi, but urea was not the most preferred form during the Prorocentrum 
donghaiense blooms. Glycine (based on potential uptake rates) was used preferentially during the P. donghaiense period (Fig. 8). Even though the glycine uptake rates were potential, not actual, rates, the general trend likely holds at ambient levels.

Uptake rates were strongly related to the DIN:DIP ratio in the water. With the progression of the blooms, not only did $\mathrm{NO}_{3}{ }^{-}$availability decrease, but that of
$\mathrm{NH}_{4}{ }^{+}$and urea actually increased, while DON remained roughly constant in availability (Fig. 2). $\mathrm{N}$-specific rates of $\mathrm{NO}_{3}^{-}$uptake increased as the DIN:DIP ratio increased (Fig. 13a). The uptake of $\mathrm{NO}_{3}{ }^{-}$ at elevated $\mathrm{NO}_{3}{ }^{-}$concentrations may be a function of both active transport and diffusion (Lomas \& Glibert 2000). However, the uptake of reduced N shows a negative relationship with the DIN:DIP ratios when the

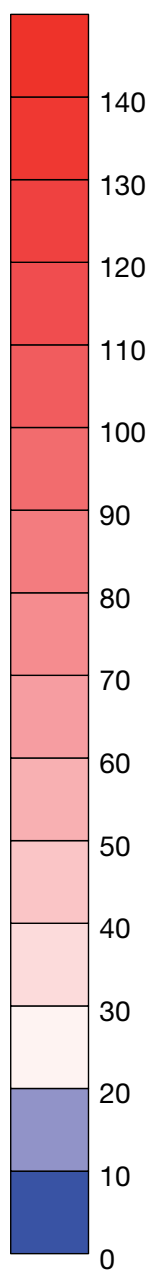

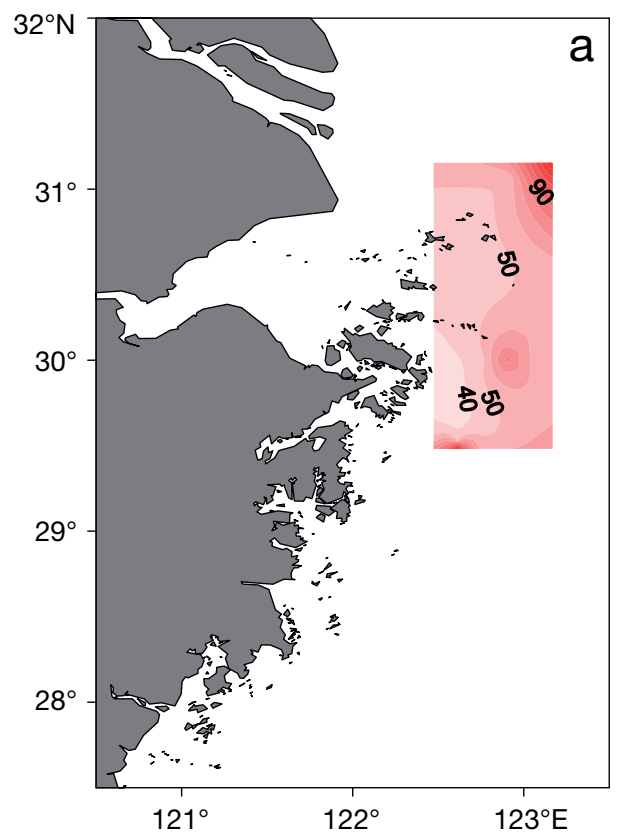


Fig. 12. Mean ratio of DIN $\left(\mathrm{NO}_{3}{ }^{-}\right.$and $\left.\mathrm{NH}_{4}{ }^{+}\right)$:DIP $\left(\mathrm{PO}_{4}{ }^{3-}\right)$ in the surface waters of the East China Sea during the spring of 2005 time series: (a) before the dinoflagellate blooms (May 7 to 13), (b) during the period of Karenia mikimotoi dominance (May 26 to June 4), (c) during the period of Prorocentrum donghaiense dominance (June 9 to 18) and (d) during the bloom decline period (June 20 to 24) 


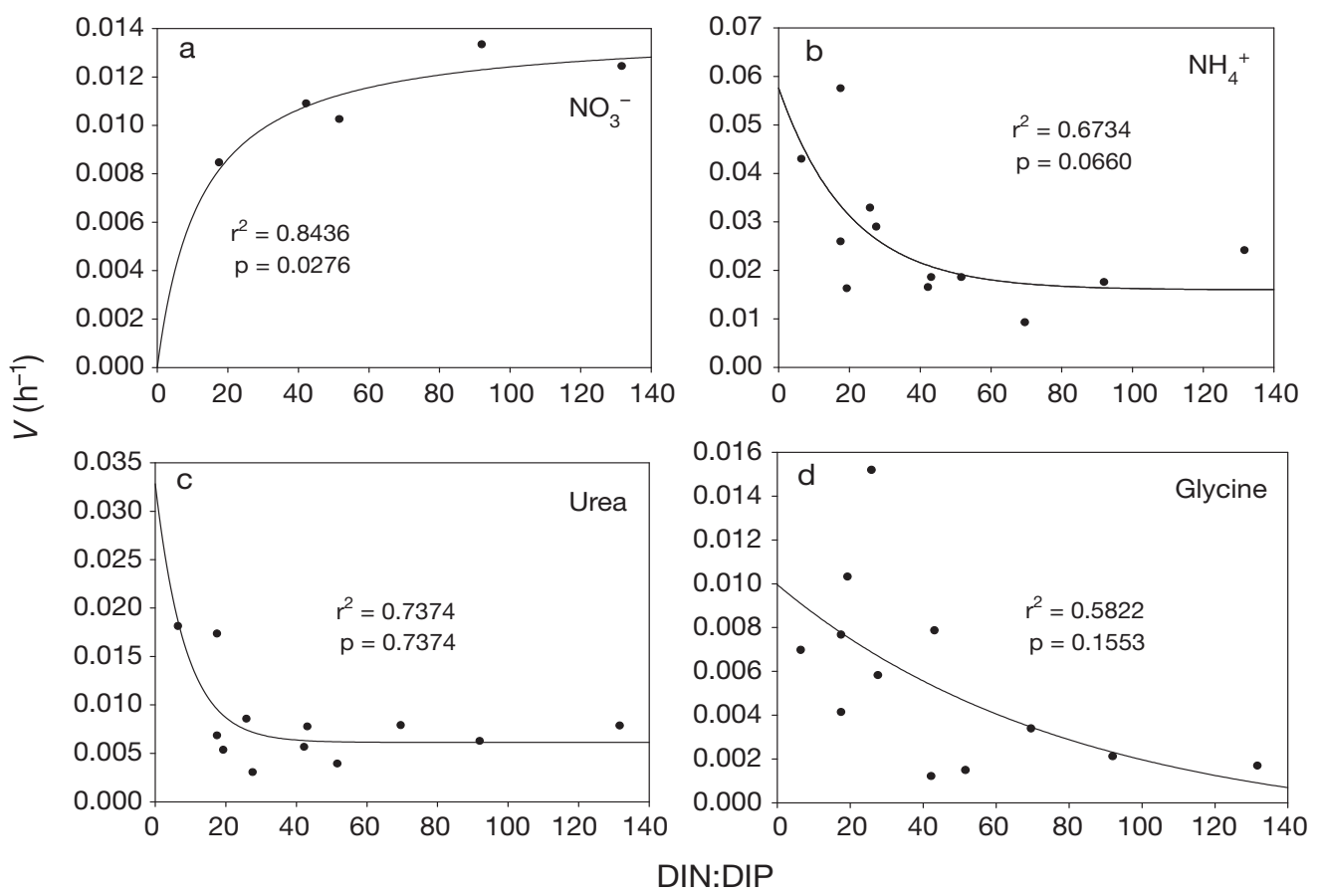

Fig. 13. The rate of nitrogen-specific uptake rates $V\left(\mathrm{~h}^{-1}\right)$ for each nitrogen form (a to d), shown as a function of the DIN:DIP ratio in the ambient surface water

ratio was larger than the Redfield ratio (Fig. 13b,c,d), indicating $P$ limitation of uptake of these substrates.

Pre-enrichment with $\mathrm{PO}_{4}{ }^{3-}$ for 2 to $24 \mathrm{~h}$ before measurement of $\mathrm{N}$-uptake rates confirmed $\mathrm{P}$ limitation. A longer $\mathrm{P}$ enrichment time resulted in even greater increases in the rates of $\mathrm{N}$ uptake. The percentage increase in reduced $\mathrm{N}$ uptake also increased during the latter stages of the time series. The water column near the Zhoushan Archipelago was under more P stress than the off-shore area and the southern part of the coast off Jejiang Province.

\section{A comparison with southwestern Florida Shelf algal nutrient dynamics}

During May 2003, a near-synoptic survey was conducted of the nutrients and phytoplankton on the southwestern Florida Shelf (Heil et al. 2007). During this period, phytoplankton communities were characterized as being dominated by Karenia brevis, a mixed non-Karenia dinoflagellate assemblage, and diatoms along different regions of the shelf. Both N:P ratios and uptake rates of $\mathrm{NO}_{3}{ }^{-}$and urea were reported for these assemblages using the same methods described herein and thus provide a spatial comparison to the ECS blooms, which varied more temporally (Heil et al. 2007). Rates of $\mathrm{NH}_{4}{ }^{+}$and glycine uptake are not available for the Florida blooms.
A direct comparison of the ambient DIN:DIP and DON:DOP ratios during both the Florida and ECS blooms shows considerable correspondence (Fig. 14a,b). In both systems, the diatom-dominated community was found in association with a high ambient DIN:DIP ratio (>45), and the Karenia spp.dominated communities were found in association with DIN:DIP ratios that were below the Redfield ratio $(<16)$. The Prorocentrum donghaiense community in the ECS and the mixed dinoflagellate assemblage off Florida were both observed to be associated with DIN:DIP ratios that more closely approximated the Redfield ratio. In both systems also, Karenia spp. were observed in waters characterized by a high DON:DOP ratio (>20), but the diatom and other dinoflagellate assemblages both proliferated in even higher ambient DON:DOP regimes (Fig. 14b). This pattern suggests that Karenia spp. in both environments may have been consuming the organic $\mathrm{N}$ source.

The uptake of DON has been suggested to be important for Karenia brevis blooms on the southwest Florida Shelf (Heil et al. 2007), and previous studies have also shown that urea is used by K. brevis (Bronk et al. 2004). In fact, a comparison of $\mathrm{N}$-specific uptake rates for the Karenia-dominated blooms in the ECS and on the southwestern Florida Shelf show nearly identical N-specific rates (Fig. 15). A comparison of urea uptake rates for diatom-dominated communities and for mixed dinoflagellate communities also re- 

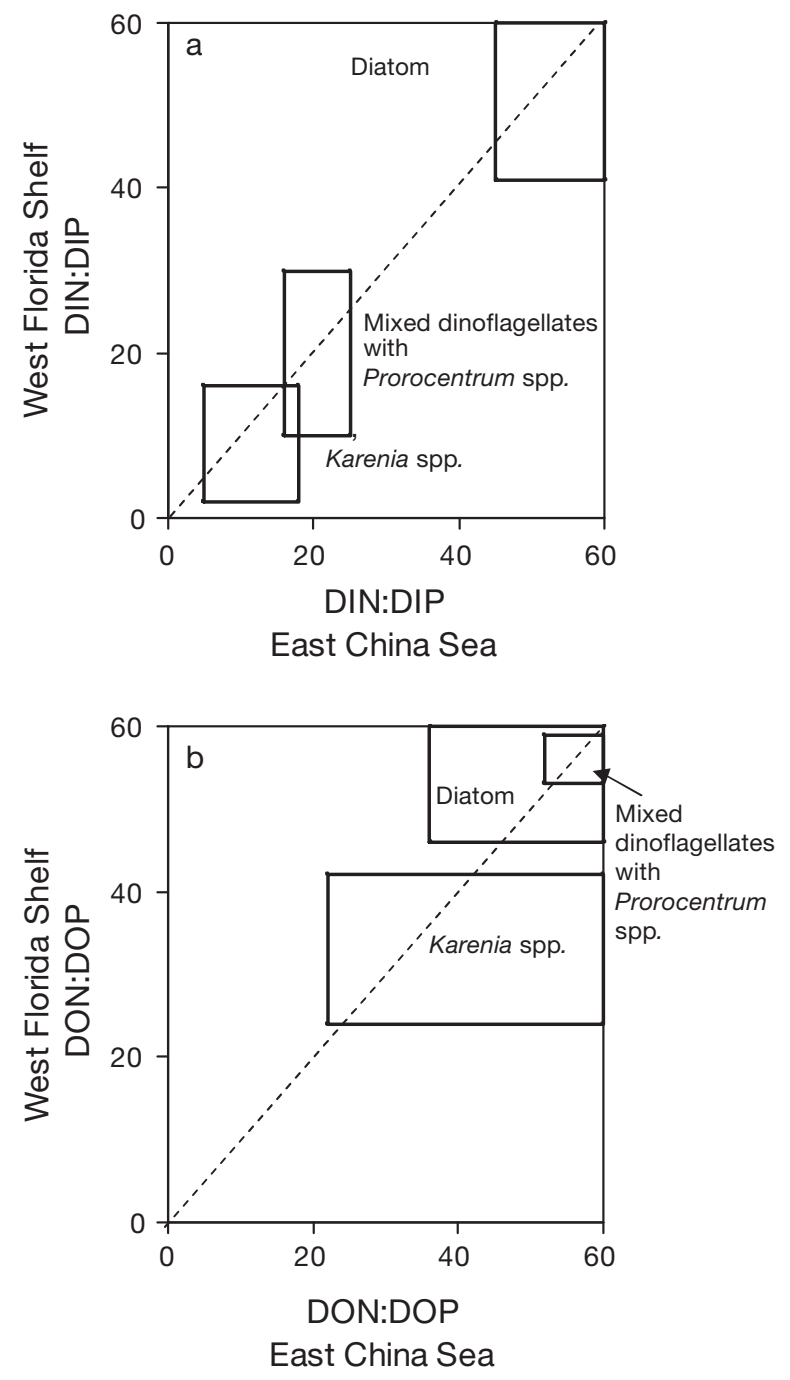

Fig. 14. Comparison of the range in ambient $\mathrm{N}$ :P ratios during different phases of the blooms in the East China Sea during May 2005 and in different phytoplankton assemblages along the southwest Florida Shelf during May 2003: (a) DIN:DIP and (b) DON:DOP. The southwest Florida Shelf data were derived from Heil et al. (2007)

vealed remarkable correspondence, but lower N-specific urea uptake rates than those for Karenia spp. (Fig. 15). Thus, there appeared to be similar general patterns in species dominance relative to $\mathrm{N}: \mathrm{P}$ ratios and comparable $\mathrm{N}$-specific uptake rates for these different systems, even though absolute biomass differed considerably.

\section{CONCLUSIONS}

In summary, the time series for the ECS showed that diatom blooms were dominant in N-replete spring conditions, but, as P limitation developed, Karenia mikimo-

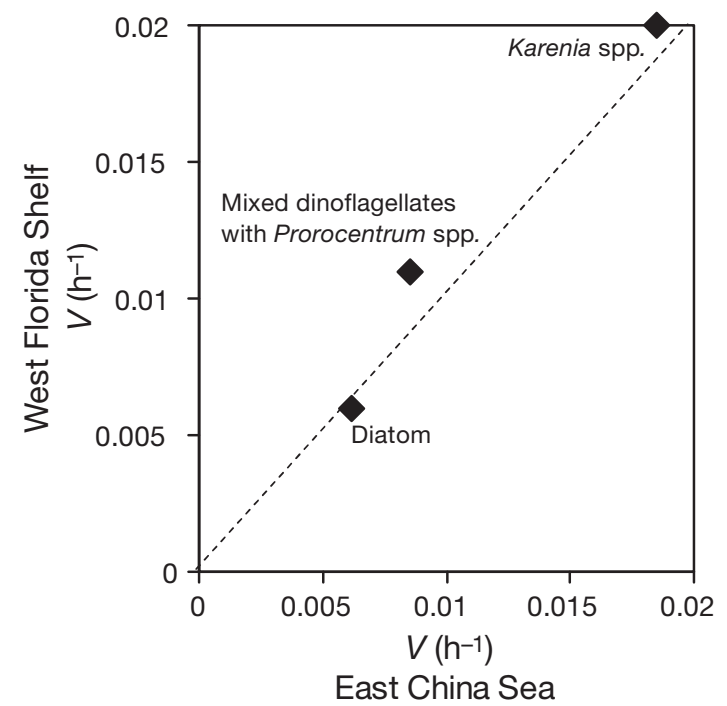

Fig. 15. Comparison of $\mathrm{N}$-specific urea uptake rates $\left(V \mathrm{~h}^{-1}\right)$ in different blooms in the East China Sea during May 2005 and in different phytoplankton assemblages along the southwest Florida Shelf during May 2003. The southwest Florida Shelf data were derived from Heil et al. (2007)

toi blooms emerged. They further drew down the available DIN as well as DON. When the DIN:DIP ratio reached a level that was close to the Redfield ratio, Prorocentrum donghaiense became the dominant dinoflagellate. During the time series, TN concentrations in the surface water column declined and could support less biomass. Organic nutrients (DON and DOP) were also important to the bloom progression, especially DOP in P-limited water during early blooms and DON in potentially N-limited water during late blooms. While all forms of reduced nitrogen $\left(\mathrm{NH}_{4}{ }^{+}\right.$, urea, and glycine) were taken up throughout the study period, urea was preferred during $K$. mikimotoi blooms, while the amino acid was preferred during $P$. donghaiense blooms. Apparently, in the ECS, nutrient regeneration was also important, as increasing concentrations of $\mathrm{NH}_{4}{ }^{+}$and urea occurred. Both stoichiometric ratios and enrichment experiments showed that $\mathrm{P}$ was the limiting nutrient early in the bloom progression and the N:P ratio was an important determinant for both biomass and $\mathrm{N}$-uptake rates. Both nutrient ratios and $\mathrm{N}$-specific rates of urea uptake in the ECS blooms were comparable to those previously reported for analogous blooms off the coast of Florida (Heil et al. 2007). These results also provide evidence of biological activities that tended to converge the N:P ratio with Redfield proportions over time.

Acknowledgements. This is a contribution of the Global Ecology and Oceanography of Harmful Algal Blooms (GEOHAB) core research project on HABs and Eutrophication, and a contribution of the Chinese Ecology and Oceanography of Harm- 
ful Algal Blooms Program (CEOHAB, grant \# 2001CB409700). J.L. was supported by the University of Maryland Center for Environmental Science (UMCES), Horn Point Laboratory, and by the NOAA South Florida Program awarded to P.M.G. (NOAA grant \#NO06NOS4780075). This is UMCES contribution number 4281.

\section{LITERATURE CITED}

Anderson DM, Glibert PM, Burkholder JM (2002) Harmful algal blooms and eutrophication: nutrient sources, composition, and consequences. Estuaries 25:704-726

Boczar BA, Palmisano AC (1990) Photosynthetic pigments and pigment-proteins in natural populations of Antarctic Sea ice diatoms. Phycologia 29:470-477

Bronk DA, Sanderson MP, Mulholland MR (2004) Organic and inorganic nitrogen uptake kinetics in field populations dominated by Karenia brevis. In: Steidinger KA, Landsberg JH, Tomas CR, Vargo GA (eds) Harmful Algae 2002, Florida Fish and Wildlife Conservation Commission, Florida Institute of Oceanography and Intergovernmental Oceanographic Commission of UNESCO, St. Petersburg, $\mathrm{Fl}, \mathrm{p}$ 80-82

Chai C, Yu ZM, Song XX, Cao XH (2006) The status and characteristics of eutrophication in the Yangtze River (Changjiang) estuary and the adjacent East China Sea, China. Hydrobiologia 563:313-328

Chang SS, Trench RK (1982) Peridinin-chlorophyll a proteins from the symbiotic dinoflagellate Symbiodinium (=Gymnodinium) microadriaticum, Freudenthal. Proc R Soc Lond B Biol Sci 215:191-210

Chen CTA, Ruo R, Pai SC, Liu CT, Wong GTF (1995) Exchange of water masses between the East China Sea and the Kuroshio off northeastern Taiwan. Cont Shelf Res 15:19-39

> Chiang KP, Chen YT, Gong GC (1999) Spring distribution of diatom assemblages in the East China Sea. Mar Ecol Prog Ser 186:75-86

Chiang KP, Chou YH, Chang J, Gong GC (2004) Winter distribution of diatom assemblages in the East China Sea. J Oceanogr 60:1053-1062

> Conley DJ, Malone TC (1992) Annual cycle of dissolved silicate in Chesapeake Bay-implications for the production and fate of phytoplankton biomass. Mar Ecol Prog Ser 81: 121-128

Degens ET, Mopper K (1976) Factors controlling distribution and early diagenesis of organic marine sediments. In: Riley JP, Chester R (eds) Chemical oceanography, Vol 6. Academic London, New York, p 60-114

Duan SW, Liang T, Zhang S, Wang LJ, Zhang XM, Chen XB (2008) Seasonal changes in nitrogen and phosphorus transport in the lower Changjiang River before the construction of the Three Gorges Dam. Estuar Coast Shelf Sci 79:239-250

Fang TH (2004) Phosphorus speciation and budget of the East China Sea. Cont Shelf Res 24:1285-1299

Fisher TR, Peele ER, Ammerman JW, Harding LW (1992) Nutrient limitation of phytoplankton in Chesapeake Bay. Mar Ecol Prog Ser 82:51-63

Glibert PM, Capone DG (1993) Mineralization and assimilation in aquatic, sediment, and wetland systems. In: Knowles R, Blackburn TH (eds) Nitrogen isotope techniques. Academic Press, New York, p 243-272

Glibert PM, Burkholder JM (2006) The complex relationships between increasing fertilization of the earth, coastal eutrophication and proliferation of harmful algal blooms.
In: Graneli E, Turner J (eds) Ecology of harmful algae. Springer-Verlag, Berlin, p 341-354

Glibert PM, Burkholder JM, Parrow MW, Lewitus AJ, Gustafson DE (2006) Direct uptake of nitrogen by Pfiesteria piscicida and Pfiesteria shumwayae, and nitrogen nutritional preferences. Harmful Algae 5:380-394

Goolsby DA, Battaglin WA (2000) Nitrogen in the Mississippi basin-estimating sources and predicting flux to the Gulf of Mexico. Fact Sheet 135-00, USGS, http://ks.water. usgs.gov/pubs/fact-sheets/fs.135-00.pdf

> Harrison PJ, Hu MH, Yang YP, Lu X (1990) Phosphate limitation in estuarine and coastal waters of China. J Exp Mar Biol Ecol 140:79-87

Heil CA, Revilla M, Glibert PM, Murasko S (2007) Nutrient quality drives differential phytoplankton community composition on the southwest Florida shelf. Limnol Oceanogr 52:1067-1078

IFIA (International Fertilizer Industry Association) (2007) IFIA database. www.fertilizer.org/ifa/Home-Page/STATISTICS

Ishikawa A, Furuya K (2004) The role of diatom resting stages in the onset of the spring bloom in the East China Sea. Mar Biol 145:633-639

Lane L, Rhoades S, Thomas C, Van Heukelem L (2000) Analytical services laboratory standard operating procedures. University of Maryland Center for Environmental Science, Cambridge, MD

> Le QH, Jovine R, Markovic P, Morse D (2001) Peridininchlorophyll $a$-protein is not implicated in the photosynthesis rhythm of the dinoflagellate Gonyaulax despite circadian regulation of its translation. Biol Rhythm Res 32: 579-594

> Lewitus AJ, White DL, Tymowski RG, Geesey ME, Hymel SN, Noble PA (2005) Adapting the CHEMTAX method for assessing phytoplankton taxonomic composition in southeastern US estuaries. Estuaries 28:160-172

Li R, Zhu M, Wang Z, Shi X, Chen B (2003) Mesocosm experiment on competition between two HAB species in East China Sea. Chin J Appl Ecol 14:1049-1054

> Li MT, Xu KQ, Watanabe M, Chen ZY (2007) Long-term variations in dissolved silicate, nitrogen, and phosphorus flux from the Yangtze River into the East China Sea and impacts on estuarine ecosystem. Estuar Coast Shelf Sci 71: 3-12

Lindroth P, Mopper K (1979) High-performance liquid-chromatographic determination of subpicomole amounts of amino acids by precolumn fluorescence derivatization with ortho-phthaldialdehyde. Anal Chem 51:1667-1674

Lomas MW, Glibert PM (2000) Comparisons of nitrate uptake, storage, and reduction in marine diatoms and flagellates. J Phycol 36:903-913

Mackey MD, Mackey DJ, Higgins HW, Wright SW (1996) CHEMTAX - a program for estimating class abundances from chemical markers: application to HPLC measurements of phytoplankton. Mar Ecol Prog Ser 144:265-283

McCarthy JJ, Taylor WR, Taft JL (1977) Nitrogenous nutrition of plankton in Chesapeake Bay. 1. Nutrient availability and phytoplankton preferences. Limnol Oceanogr 22: 996-1011

Revilla M, Alexander J, Glibert PM (2005) Urea analysis in coastal waters: comparison of enzymatic and direct methods. Limnol Oceanogr Methods 3:290-299

Richardson TL, Pinckney JL (2004) Monitoring of the toxic dinoflagellate Karenia brevis using gyroxanthin-based detection methods. J Appl Phycol 16:315-328

Shen ZL (2006) Phosphorus and silicate fluxes in the Yangtze River. Acta Geogr 60:741-751

Shen Z, Liu Q, Zhang SM, Miao H, Zhang P (2003) A nitrogen 
budget of the Changjiang river catchment. Ambio 32: 65-69

Tang TY, Tai JH, Yang YJ (2000) The flow pattern north of Taiwan and the migration of the Kuroshio. Cont Shelf Res 20:349-371

Tang DL, Di BP, Wei GF, Ni IH, Oh IS, Wang SF (2006) Spatial, seasonal and species variations of harmful algal blooms in the South Yellow Sea and East China Sea. Hydrobiologia 568:245-253

Tango PJ, Magnien R, Butler W, Luckett C, Luckenbach M, Lacouture R, Poukish C (2005) Impacts and potential effects due to Prorocentrum minimum blooms in Chesapeake Bay. Harmful Algae 4:525-531

Turner RE, Rabalais NN, Nan ZZ (1990) Phytoplankton biomass, production and growth limitations on the Huanghe (Yellow River) continental shelf. Cont Shelf Res 10: 545-571

> Valderrama JC (1981) The simultaneous analysis of total nitrogen and total phosphorus in natural waters. Mar Chem 10:109-122

Van Heukelem L, Thomas CS (2001) Computer-assisted highperformance liquid chromatography method development with applications to the isolation and analysis of phytoplankton pigments. J Chromatogr A 910:31-49

Editorial responsibility: Peter Verity,

Savannah, Georgia, USA
Wang Z, Li R, Zhu M, Chen B, Hao Y (2006b) Study on population growth processes and interspecific competition of Prorocentrum donghaiense and Skeletonema costatum in semi-continuous dilution experiments. Adv Mar Sci 24: 495-503 (in Chinese)

Xing GX, Zhu ZL (2002) Regional nitrogen budgets for China and its major watersheds. Biogeochemistry 57:405-427

Yan WJ, Zhang S (2003) The composition and bioavailability of phosphorus transport through the Changjiang (Yangtze) River during the 1998 flood. Biogeochemistry 65:179-194

Yao P, Yu ZG, Deng CM (2006) Pigment signatures of some diatoms isolated from China seas. Acta Oceanol Sin 25: 108-118

Yin KD, Song XX, Sun J, Wu MCS (2004) Potential P limitation leads to excess $\mathrm{N}$ in the Pearl River estuarine coastal plume. Cont Shelf Res 24:1895-1907

Zhang J, Liu SM, Ren JL, Wu Y, Zhang GL (2007) Nutrient gradients from the eutrophic Changjiang (Yangtze River) estuary to the oligotrophic Kuroshio waters and re-evaluation of budgets for the East China Sea shelf. Prog Oceanogr 74:449-478

Zhou M, Yan T, Zou J (2003) Preliminary analysis of the characteristics of red tide areas in Changjiang River estuary and its adjacent sea. Chin J Appl Ecol 14:1031-1038

Submitted: August 14, 2008; Accepted: February 13, 2009 Proofs received from author(s): April 27, 2009 